Climate and productivity affect total mercury concentration and bioaccumulation rate of fish along a spatial gradient of subarctic lakes

\title{
Ahonen, Salla
}

2018-10-01

Ahonen , S , Hayden , B , Leppänen , J J \& Kahilainen , K K 2018 , ' Climate and productivity affect total mercury concentration and bioaccumulation rate of fish along a spatial gradient of subarctic lakes ' , The Science of the Total Environment , vol. 637-638 , pp. 1586-1596 . https://doi.org/10.1016/j.scit

http://hdl.handle.net/10138/315093

https://doi.org/10.1016/j.scitotenv.2018.04.436

cc_by_nc_nd

acceptedVersion

Downloaded from Helda, University of Helsinki institutional repository.

This is an electronic reprint of the original article.

This reprint may differ from the original in pagination and typographic detail.

Please cite the original version. 
4 Salla A. Ahonen ${ }^{1,}{ }^{*}$, Brian Hayden ${ }^{2}$, Jaakko J. Leppänen ${ }^{1}$, Kimmo K. Kahilainen ${ }^{3}$

$5{ }^{1}$ Department of Environmental Sciences, University of Helsinki, P.O. Box 65, FI-00014, Finland

$6 \quad{ }^{2}$ Canadian Rivers Institute, Biology Department, University of Brunswick, Canada

${ }^{3}$ Faculty of Biosciences, Fisheries and Economics, The Norwegian College of Fishery Science, UiT The

Arctic University of Norway, 9037 Troms $\varnothing$, Norway

9

*Corresponding author. E-mail address: salla.a.ahonen@helsinki.fi

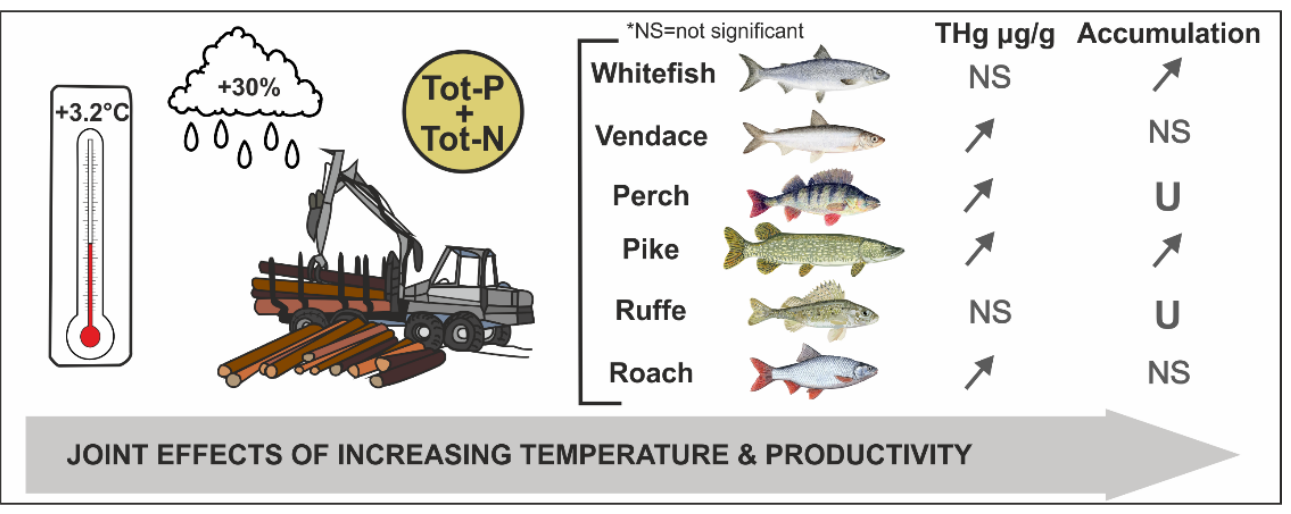

\section{HIGHLIGHTS}

16 - Climate and productivity effects on fish mercury (THg) in 18 Subarctic lakes were studied.

17 - THg concentration and bioaccumulation rates of 6 fish species muscle were examined.

- Temperature and productivity were correlated with THg concentration in 4 species.

19 - Higher climate-productivity was linked to faster THg bioaccumulation in 2 species.

20 - Joint environmental stressors should be considered in future THg studies on fish. 


\section{ABSTRACT}

Climate change is resulting in increased temperatures and precipitation in Subarctic regions of Europe. These changes are extending tree lines to higher altitudes and latitudes, and enhancing tree growth enabling intensification of forestry into previously inhospitable Subarctic regions. The combined effects of climate change and land-use intensification extend the warm, open-water season in Subarctic lakes and increase lake productivity and may also increase leaching and methylation activity of mercury within the lakes. To assess the joint effects of climate and productivity on total mercury ( $\mathrm{THg}$ ) bioaccumulation in fish, we conducted a space-for-time substitution study in 18 tributary lakes of a Subarctic watercourse forming a gradient from cold pristine oligotrophic lakes in the northern headwaters to warmer and increasingly human-altered mesotrophic and eutrophic systems in the southern lower reaches.

Increasing temperature, precipitation, and lake productivity were predicted to elevate length- and age-adjusted $\mathrm{THg}$ concentrations, as well as $\mathrm{THg}$ bioaccumulation rate (the rate of $\mathrm{THg}$ bioaccumulation relative to length or age) in muscle tissue of European whitefish (Coregonus lavaretus), vendace (Coregonus albula), perch (Perca fluviatilis), pike (Esox lucius), roach (Rutilus rutilus) and ruffe (Gymnocephalus cernua).

A significant positive relationship was observed between age-adjusted THg concentration and lake climate-productivity in vendace $\left(r^{2}=0.50\right)$, perch $\left(r^{2}=0.51\right)$, pike $\left(r^{2}=0.55\right)$ and roach $\left(r^{2}=0.61\right)$. Higher climate-productivity values of the lakes also had a positive linear $\left(p i k e ; r^{2}=0.40\right)$ and whitefish $; r^{2}=0.72$ ) or $u$-shaped (perch; $r^{2}=0.64$ and $r u f f e ; r^{2}=0.50$ ) relationship with THg bioaccumulation rate. Our findings of increased adjusted THg concentrations in planktivores and piscivores reveal adverse effects of warming climate and increasing productivity on these Subarctic fishes, whereas less distinct trends in THg bioaccumulation rate suggest more complex underlying processes. Joint 
environmental stressors such as climate and productivity should be considered in ongoing and future monitoring of mercury concentrations.

KEYWORDS: Climate change; Heavy metal; Intensive forestry; Land use; Temperature

\section{INTRODUCTION}

Recent climate change has greatly impacted Arctic regions, resulting in temperature and precipitation increases above global average (IPCC, 2015). Furthermore, increased global interests in the Arctic and Subarctic regions are intensifying the resource use in terrestrial and aquatic ecosystems (Huntington et al., 2007; Wrona et al., 2013; Gordon et al., 2018). Enhanced vegetation growth and tree-line extension in the Subarctic, due to climate change, are enabling and intensifying forestry practices associated with peatland ditching and site-preparation practices that expose the mineral soil and increase nutrient and organic carbon run-off (Serreze et al., 2000; Bates et al., 2008; Nieminen et al., 2015). Nutrient and heavy metal loadings are often connected to DOC concentrations, as DOC acts as a carrier of them from catchments to aquatic ecosystem (Porvari and Verta, 2003; de Wit et al., 2014). In freshwater ecosystems, these environmental changes result in an extended open-water season, increased load and concentrations of nutrients and DOC leading to elevated productivity (Karlsson et al., 2009; Sarkkola et al., 2009; Nieminen et al., 2015).

Mercury $(\mathrm{Hg})$ is a toxic heavy metal, the methylated form $(\mathrm{MeHg})$ of which bioaccumulates in body tissues of fishes (Morel et al., 1998; Sonesten, 2003a; Trudel and Rasmussen, 2006) and biomagnifies to higher trophic levels in food webs (Jernelöv and Lann, 1971; Morel et al., 1998; Lavoie et al., 2013). Hg originates from natural and anthropogenic sources, but the relative proportion of anthropogenically derived $\mathrm{Hg}$ has increased since the Industrial Revolution (Pacyna et al., 2010; UNEP, 2013). In relatively pristine Subarctic regions, Hg primarily enters aquatic 
ecosystems through atmospheric deposition of inorganic Hg (Schroeder and Munthe, 1998; AMAP, 2011; Stern et al., 2012).

Methylation of inorganic $\mathrm{Hg}$ to MeHg can occur in lake sediment, water column, and in catchment soils, principally by sulphur-oxidizing bacteria (Morel et al., 1998). In Subarctic lakes, the production of MeHg predominantly occurs in the anoxic hypolimnion and lake sediment (Eckley and Hintelmann, 2006), whilst demethylation dominates in the oxygenated photic zone (Morel et al., 1998; Chen et al., 2003). The influence of climate change on methylation-demethylation processes and $\mathrm{Hg}$ concentrations in the water and aquatic biota is highly complex and likely system dependent. Mercury methylation rate is positively related to temperature (Bodaly et al., 1993), whereas negative or no connection has been found between demethylation and temperature (Bodaly et al., 1993; Canário et al., 2007). Yang et al. (2016) observed higher MeHg production in warm (+8 $\left.{ }^{\circ} \mathrm{C}\right)$ versus cold $\left(-2^{\circ} \mathrm{C}\right)$ soils, suggesting an enhanced production of $\mathrm{MeHg}$ in the warming Arctic soils. $\mathrm{A}$ positive relationship between temperature in lake epilimnion and total mercury $(\mathrm{THg})$ levels in fish was also observed in the Canadian Subarctic (Evans et al., 2005a, b), possibly due to temperatureinduced higher net methylation rate and $\mathrm{Hg}$ inputs from watersheds.

Climate change is resulting in increased leaching of nutrients and DOC in the Subarctic, and this may also be expected to increase the availability of $\mathrm{Hg}$ in the water column and aquatic food webs, as DOC is a carrier of Hg (Grigal, 2002; Rydberg et al., 2010). Elevated DOC load is also causing browning and lower light penetration in the water column, which expands the anoxic zone suitable for methylation (Lehnherr, 2014; Klapstein et al., 2018). Decomposition of organic matter further stimulates the activity of microbial methylation (Bravo et al., 2017), but DOC also binds $\mathrm{Hg}$, reducing its bioavailability for methylation (Ullrich et al., 2001). The origin of the organic matter has influence. For example, lakes with high levels of algal-derived organic matter exhibit increased bacterial activity and methylation rate. In addition, terrigenous organic matter has been connected to 
ultimately higher MeHg concentrations (Bravo et al., 2017). Thus, modification of terrestrial soil, due to intensive forestry, can elevate the availability of MeHg to aquatic systems and wildlife (Morel et al., 1998; Lehnherr, 2014).

Studies assessing how lake productivity influences mercury concentrations and bioaccumulation rates of fishes have, to date, proved inconclusive. In a worldwide study, total phosphorus level was found to have a negative connection to $\mathrm{MeHg}$ biomagnification, possible through biomass dilution of THg in primary producers as well as elevated growth rate of organisms at higher trophic levels (Lavoie et al., 2013). A multi-lake study from northeastern North America showed that relatively low productivity in lakes was connected to higher $\mathrm{Hg}$ bioaccumulation in food webs (Chen et al., 2005). However, a positive connection between phosphorus level and biomagnification of THg in food webs was found in a Canadian lake (Kidd et al., 2012), and fish communities especially in lakes with forested watersheds were shown to have high concentrations of $\mathrm{Hg}$ (Sonesten, 2003b; Chen et al., 2005).

The highest THg concentrations in aquatic biota are generally found in top predators with long lifespans (Cabana and Rasmussen, 1994). Mercury in the water column is integrated into pelagic primary producers by active transport and passive diffusion (Pickhardt and Fisher, 2007), whereas organisms at higher trophic levels predominantly gather $\mathrm{Hg}$ from their diet (Hall et al., 1997). The proportion of MeHg of the THg in tissues increases with trophic level, and typically makes up over $90 \%$ of the THg in fish muscle (Watras et al., 1998; Madenjian et al., 2016). Several traits including foraging guilds, thermal guilds, and life-history can all influence the THg concentrations in fish muscle (Trudel and Rasmussen, 2006; Karimi et al., 2016; Thomas et al., 2016). Fish species foraging on pelagic prey typically have higher THg concentrations than benthic feeding fishes, due to higher MeHg concentrations often found in zooplankton than littoral benthic prey (Power et al., 2002; Karimi et al., 2016; Thomas et al., 2016). Moreover, increasing growth rate reduces THg 
concentrations in fish through growth dilution, while starvation has the opposite effect (Simoneau et al., 2005; Keva et al., 2017).

The Subarctic offers a unique region to evaluate the joint effects of climatic and land-use variables on THg concentrations and bioaccumulation rate in fish. Subarctic watercourses represent a gradient ranging from pristine cold and oligotrophic lakes to increasingly human-modified and warmer more productive lakes. This gradient from north to south encompasses the distribution limits of several fish species, as fish communities are dominated by salmonids to percids to cyprinids along increasing air temperature (Hayden et al., 2017). Climate related changes in consumer community structure and functional community structure may also have a significant bearing on the $\mathrm{Hg}$ dynamics in Subarctic lakes. Climate change and associated increase in lake productivity are modifying the fish communities in Subarctic lakes as warm-water adapted species are expanding their ranges northwards (Rolls et al., 2017). The presence of novel fish species assemblages modifies consumer community structure, selective foraging, resource competition, and the number of trophic linkages in food webs, all of which can affect Hg burden to piscivores (Thomas et al., 2016). As such, Subarctic environmental gradients represent an opportunity to predict future trends of fish communities and create a realistic natural setting to assess climate and productivity effects on $\mathrm{THg}$ in fish at a landscape level (Hayden et al., 2017).

We conducted a space-for-time study on a Fennoscandian Subarctic watercourse gradient from north to south to determine how THg concentrations and bioaccumulation rates of six Subarctic fish species are influenced by lake temperature and productivity. The selected fish species are abundant throughout the study area, but differ in their thermal and foraging guilds (Magnuson et al., 1979; Hayden et al., 2013; Thomas et al., 2016). Hg in three generalist species that forage across both pelagic and littoral habitats were assessed: the cold-water adapted European whitefish (Coregonus lavaretus) that dominate oligotrophic lakes; the cool-water species Eurasian perch (Perca fluviatilis) 
141 that dominates mesotrophic lakes, and the warm-water species roach (Rutilus rutilus) found in 142 eutrophic lakes (Hayden et al., 2017). Perch undergo ontogenetic dietary shifts from zooplankton to 143 benthic macroinvertebrates, and finally to fish prey, whereas whitefish and roach feed almost 144 exclusively on invertebrate prey (Hayden et al., 2014a). In addition, two specialist taxa were studied: 145 vendace (Coregonus albula), a cold-water pelagic zooplanktivore, and ruffe (Gymnocephalus 146 cernua), a cool-water specialist benthivore (Hayden et al., 2013; Thomas et al., 2016). Pike (Esox 147 lucius), a cool-water obligate piscivore, were also sampled. This species is primarily associated with 148 littoral habitat and feeds on a wide range of prey fish species (Kahilainen and Lehtonen, 2003). All study species forage visually, but percids and cyprinids are more adapted to feeding under increased turbidity than cold-water salmonids (Rolls et al., 2017). Ruffe, perch, and roach are expanding their ranges towards higher latitudes and altitudes in this area (Hayden et al., 2013, 2014a).

In the current study, we assessed how climate and lake productivity, lake morphometry and 153 catchment properties influence length- and age-adjusted THg concentrations, and the bioaccumulation rate of THg in whitefish, vendace, perch, pike, roach, and ruffe. Using a space-fortime substitution approach, we tested whether $\mathrm{THg}$ concentrations in fish were related to lake temperature-productivity along a Subarctic watercourse with climatic and land-use gradients from north to south (Hypothesis 1 ). We hypothesized that $\mathrm{THg}$ bioaccumulation rates relative to fish length and age (the slope of regression between THg and length or age) would increase along the gradient from north to south (Hypothesis 2), since increase in temperature and productivity of lakes cause shifts in community structure, elevating the amount of pelagic derived energy (Hayden et al., 2017; Leppänen et al., 2017).

\section{MATERIAL AND METHODS}


166

167

were sampled in northern Fennoscandia (Fig. 1). The lakes are distributed along a climate and productivity gradient from northern to southern Lapland where the open water season air temperature, precipitation, and total phosphorus increased by $3.2{ }^{\circ} \mathrm{C}$ (ranging from 8.4 to $11.6{ }^{\circ} \mathrm{C}$ ), $30 \%$ (ranging from 197 to $257 \mathrm{~mm}$ ), and total $45 \mu \mathrm{g} / \mathrm{L}$ (ranging from 3 to $48 \mu \mathrm{g} / \mathrm{L}$ ), respectively (Table 1). Conservative climate change models for this region predict increases in temperature and productivity matching the temperature, precipitation, and productivity measured ranges here by the end of this century (IPCC, 2015). Land-use related variables, such as total length of artificial ditches and tree volume in the catchment increased along the same gradient, indicating intensification of land use.

Lake characteristics ranged from clear oligotrophic $(<15 \mu \mathrm{g} / \mathrm{L}$ total phosphorus) lakes $(1-7,9)$ in the north to increasingly mesotrophic $(15-29 \mu \mathrm{g} / \mathrm{L}$ total phosphorus, lakes $8,10-13)$ and eutrophic lakes (>29 $\mu \mathrm{g} / \mathrm{L}$ total phosphorus, lakes $14-18$ ) towards the south (Fig. 1, Table 1). The highest latitude lakes $(1-7,9)$ are surrounded by mountain birch forest, with low human population density and land use consisting mainly of reindeer herding. Theoretical compensation depth, the depth at which $1 \%$ of surface light intensity was detectable, decreases towards the south. The mesotrophic and slightly more colored lake (8) is located below the northern distribution limit of Scots pine (Pinus sylvestris) with increasing human population density. The lower latitude mesotrophic lakes (10-13) are located below the northern distribution limit of Norway spruce (Picea abies) with higher human population density and forestry as well as nature tourism. The eutrophic lakes (14-18) are characterized by the highest human population density in the catchment among the study lakes, as well as intensive forestry, with associated site-preparation and ditching practices, as the principal forms of land use, enhancing nutrient loading to the lakes, and thus increasing the water color (Jussila et al., 2014). 


\subsection{Environmental variables}

The climate and lake environmental variables were primarily obtained from long-term archives.

192 Geographic location and altitude of each lake were obtained from the National Land Survey of Finland. Average air temperature $\left({ }^{\circ} \mathrm{C}\right)$ and precipitation $(\mathrm{mm})$ during the open water season (June-September) were obtained for each lake from long-term data (1981-2010; Finnish Meteorological Institute, Klein Tank et al., 2002) from six weather stations located through the study area (Fig. 1, Table 1). Total phosphorus and nitrogen data were obtained during the fish sampling or regional monitoring programs of the same year (Lapland Centre for Economic Development, Transport and Environment). The lake morphometric variables included lake area $\left(\mathrm{km}^{2}\right)$, maximum depth $(m)$, mean depth $(m)$ and lake volume $\left(\mathrm{m}^{3}\right)$ that were obtained from Hertta-database (Finnish Environment Institute) or derived from data of bathymetric maps created by using an echosounderchartplotter device (LCX-112C GPS-chartplotter: Lowrance, Tulsa, Oklahoma, U.S.A.). Visible light intensity (400-700 nm) was measured in the water column using a LI-COR LI-250A light meter (LICOR Biosciences, Lincoln, NE, U.S.A.). This data was used to calculate the compensation depth that defined the habitat border between the littoral and pelagic zones. The catchment variables were entirely derived from data archives, where the land-use variables were derived from CORINE LandCover data implemented in VALUE-tool (Finnish Environmental Institute). These data were used to calculate catchment area $\left(\mathrm{km}^{2}\right)$ and relative proportions (\%) of different land-use practices (urban, agriculture, forest, sparse vegetation, wetland and water) in catchment and transformed to area coverages e.g. forest (ha). Tree volume data for the forested area was obtained from the open access data bank (The Natural Resources Institute Finland). The total length of artificial ditches (km) in the catchment of each lake was analyzed from open map data (National Land Survey of Finland). 
Tree volume $\left(\mathrm{m}^{3} / \mathrm{ha}\right)$ and ditch length $\left(\mathrm{km} / \mathrm{km}^{2}\right)$ variables were calculated for forested and wetland catchments. Analyses were conducted using ESRI ArcMap 10.3.1 software.

\subsection{Fish species and field sampling}

We sampled six fish species across the 18 study lakes: whitefish, vendace, perch, pike, roach, and ruffe. Whitefish and pike inhabited almost all the study lakes, whereas perch, roach, and ruffe were absent from the northernmost lakes (Table 2). Vendace and roach were abundant in the lower latitudes. Fish were caught over five consecutive days between late-August and September in 2009-2013, to control for potential seasonal THg variation in muscle tissue (Kahilainen et al., 2016; Keva et al., 2017). The target sample size was 30 individuals for each species in each lake, if possible. The fish were caught by gillnet series with eight nets (size: 30 x 1.8 m, knot-to-knot mesh size: 12 , $15,20,25,30,35,45$ and $60 \mathrm{~mm}$ ), as well as one Nordic multi-mesh gillnet (size $30 \times 1.5 \mathrm{~m}$, mesh sizes $5-55 \mathrm{~mm}$ ) with 12 equidistant panels of $2.5 \mathrm{~m}$. Pike samples were supplemented with hookand-line sampling due to their comparatively low density. Nets were set overnight $(10-12 \mathrm{~h})$ in littoral, profundal, and pelagic habitats in each lake, except shallow full littoral lakes that lack pelagic and profundal zones. All these principal habitats were sampled for at least three nights. Fish were removed from nets, euthanized by cerebral concussion causing an immediate death and placed on ice during transport to the laboratory.

All fish were identified to species and total length $( \pm 1 \mathrm{~mm})$ and age were determined. For whitefish and vendace, the first left gill arch was dissected and the number of gill rakers counted for morph and species identification purposes (Kahilainen et al., 2011a, b). In this region, whitefish may occur as sympatric morphs having different number of gill rakers, diet, growth, and muscle $\mathrm{THg}$ concentrations (Kahilainen and $\varnothing$ stbye, 2006; Harrod et al., 2010; Kahilainen et al., 2017). In the study lakes, whitefish occur as a single generalist morph, except Lake Ropi where we selected only 
the littoral morph for this study (Hayden et al., 2013). Fish ages were determined using the most reliable hard structures for each species including burned cross-sections of otoliths, bones, and scales pressed on polycarbonate plates (Thomas et al., 2016). Two hard structures were simultaneously used to improve the aging accuracy (Kahilainen et al., 2017). Aging of pike was done using cleithrum bone and scale impressions. For perch operculum bone and burned cross-sections of otoliths were used, while for the other species (whitefish, vendace, roach, ruffe) clear and burned cross-sections of otoliths as well as scale impressions were used (Kahilainen et al., 2003, 2011b; Hayden et al., 2014a, 2015). Dorsal muscle tissue samples were taken from each sample, frozen at $-20^{\circ} \mathrm{C}$, freeze-dried for 48 hours, and grinded with glass rod to fine powder for $\mathrm{THg}$ analyses.

\subsection{Total mercury analyses}

Total mercury ( $\mathrm{THg}$ ) concentrations ( $\mu \mathrm{g} \mathrm{g}^{-1}$ dry mass) were obtained using a Direct Mercury Analyser (Milestone DMA 80). Two replicates of each sample were analyzed to assess sample variability. A blank control and certified reference material (DORM-4) with known THg concentration (mean $\pm \mathrm{SD}, 0.410 \pm 0.055 \mu \mathrm{g} \mathrm{g}^{-1}$ ) were included at the beginning and end of each analytical run (mean $\pm \mathrm{SD}, 0.404 \pm 0.019 \mu \mathrm{g} \mathrm{g}{ }^{-1}$, mean recovery $98.6 \%, \mathrm{n}=390$ ). The $\mathrm{THg}$ concentration of each sample used in statistical analyses was derived by calculating the mean value of duplicates after subtracting the mean blank control values (mean $\pm S D, 0.002 \pm 0.001 \mu g^{-1}, n=390$ ). The mean of the duplicates for each sample was accepted for subsequent analyses only when the relative standard deviation (RSD) was less than $10 \%$. A randomized subset of 30 individuals was chosen from populations where sample size was greater than 30 to make systems comparable.

Due to a strong positive relationship between $\mathrm{THg}$ concentration and fish length/age, THg concentrations of fish were corrected for length/age prior to conducting inter-population comparisons (Sonesten, 2003a; Braaten et al., 2017). We first developed linear regression equations 
260

for fish THg and length/age of each species in each lake (Table S4-5, Fig. S1-12). The equations were solved for the mean length and age of each species, resulting in a single mean length- and agecorrected THg value for each species within each lake (the average length and age of each species calculated from all studied lakes; Table 2) (Braaten et al., 2017). In populations where the relationship between THg and length or age was below statistically significant level, the length- and age-adjusted values were obtained by calculating the mean of the species-specific THg concentrations near mean length $( \pm 2.5 \mathrm{~cm})$ and age ( \pm 1.5 years). Length- and age-adjusted THg concentrations were used for all subsequent statistical analyses examining population level differences.

\subsection{Statistical analyses}

Collinearity among environmental variables was first tested with linear regression analyses, and variables with $r^{2}<0.70$ were chosen for the further analyses. Principal component analysis (PCA) was used for the remaining variables to receive PC score for each study lake along environmental gradients using PC components. PC components explaining $>10 \%$ of the variation were considered relevant for further evaluation of trends with $\mathrm{THg}$ concentrations and bioaccumulation rates. Lake PC scores were negative transformed $\left(*_{-}-1\right)$ for THg analyses, because their connections to warmer climate and increased lake productivity were visually clearer compared to original scores (for original PC scores, see Table 1, Fig. 2).

Statistical testing of Hypothesis 1: Linear regression analysis was used to test the relationship between length- or age-adjusted THg concentration and lake PC scores. Lake-specific populations of each species were used for regression analyses only if the sample size was greater or equal to six.

Statistical testing of Hypothesis 2: The relationship between $\mathrm{THg}$ bioaccumulation rate (i.e. the slopes of significant linear regressions between $\mathrm{THg}$, and length or age) and lake PC scores 
representing different environmental gradients were also tested using simple linear regression analysis. In addition, non-linear quadratic models were tested for species having visually non-linear relationship between PC scores and THg bioaccumulation rate. Only populations with significant bioaccumulation of THg relative to length or age could be chosen for the subsequent analyses of the bioaccumulation rate.

The statistical significance limit to reject the null hypothesis (alpha) was 0.05 for all analyses. Adjusted R-squared (adj. $\mathrm{r}^{2}$ ) values were used for interpreting the significant results. For simplicity, term $r^{2}$ is used in tables. All analyses were conducted using SPSS Statistics 24 (IBM Corp., Armonk, NY, U.S.A.) or R (R Core Team, 2017).

\section{RESULTS}

\subsection{Environment, lake morphometry and catchment variation}

The collinearity of environmental variables was considerable due to their nature, and thus we used the remaining 14 variables in PCA (Table 1; see the excluded variables in Table S1). The first three PC components explained a total of $84 \%$ of the variation among lakes (Fig. 2). PC1 explained $52 \%$ of the variation and included variables related to climate and lake productivity (i.e. altitude, air temperature, precipitation, total phosphorus, and compensation depth) and to catchment related variables (i.e. forest percentage, ditch length and tree volume in the catchment area; see loadings in the supplementary Table S2). PC1 lake scores were correlating negatively to lake climateproductivity (Fig. 2, Table 1). The second axis (PC2) explained $19 \%$ of the variance, represented mainly lake morphometric characteristics (i.e. mean depth, lake volume, lake and catchment areas, wetland proportion in catchment, see Table S2) and was negatively correlated with lake size (Fig. 2, Table 1). The third axis (PC3) explained $13 \%$ of the variance in lakes including catchment properties (e.g. catchment-lake ratio and catchment area, as well as ditch length, wetland, and tree 
proportions in catchment with much lower importance, see Table S2) with values correlating negatively to catchment magnitude (Fig. 2, Table 1). Please note, that negative transformed values $\left({ }^{*}-1\right)$ were used for lake scores for the subsequent analyses of the relationship between $\mathrm{THg}$ concentration or THg bioaccumulation rate, and PC factors.

\subsection{Hypothesis 1: Connection between THg concentrations and lake PC scores}

Fish sample sizes were highly variable within species and lakes, partially due to differing distribution limits of each species (Table 2). Whitefish and pike inhabited almost all the study lakes, while other species were absent in the northernmost lakes. THg concentrations varied substantially within species, the highest length- and age-adjusted THg concentrations being found in pike, followed by perch and roach, and the lowest in vendace, ruffe, and whitefish (Table 2). Bioaccumulation of THg relative to length and age varied substantially among fish species (Table S45, Fig. S1-12). THg bioaccumulation relative to length and age were significant for vendace, perch, pike, and ruffe in all or nearly all of the lakes, whereas whitefish and roach had significant regression coefficients in approximately half of the cases (Table S4-5 and Fig. S1-12). Significant coefficients were positive for all the species, except for whitefish having a significant negative relationship between THg concentration and length in two northernmost lakes (Fig. S1).

Lake-specific length- and age-adjusted THg concentrations displayed statistically significant relationships with PC1 (climate-productivity), but were unrelated to either PC2 (lake morphometry) or PC3 (catchment magnitude; see Tables 3 and Table S3, Fig. 3 and Fig. S13-14). Length-adjusted THg had a significant positive relationship with lake PC1 score for perch (adj. $r^{2}=0.50, p<0.01$ ), pike $\left(\operatorname{adj} . r^{2}=0.29, p<0.05\right)$ and roach $\left(\operatorname{adj} . r^{2}=0.57, p=0.05\right)$, whereas relations were below statistically significant levels for whitefish, ruffe and vendace. Significant positive relationships between ageadjusted THg concentration and PC1 were found for vendace (adj. $\left.r^{2}=0.50, p<0.05\right)$, perch 
$\left(\operatorname{adj} . r^{2}=0.51, p<0.01\right)$, pike (adj. $\left.r^{2}=0.55, p<0.005\right)$ and roach $\left(\operatorname{adj} . r^{2}=0.61, p<0.05\right)$, while linear models for whitefish and ruffe were non-significant (Table 3).

\subsection{Hypothesis 2: Bioaccumulation rate of $\mathrm{THg}$ relative to lake $P C$ scores}

Bioaccumulation rate of THg relative to length or age (the slope of linear regression for each lake and species, see Table S4-5) showed significant relationships with lake PC1 and PC3 scores, but not with PC2 scores (Table 3, Fig. 3, Table S3, Fig. S13-14). Due to low number of populations having statistically significant bioaccumulation of THg relative to length $(n=3)$ or age $(n=4)$, roach was omitted from these analyses.

The bioaccumulation rate of whitefish $\mathrm{THg}$ relative to length displayed a positive linear relationship with PC1 (adj. $\left.\mathrm{r}^{2}=0.34, \mathrm{p}<0.05\right)$ (Table 3, Fig. 3). Non-linear u-shaped relationships were found for perch (adj. $\left.r^{2}=0.73 ; p<0.005\right)$ and ruffe (adj. $\left.r^{2}=0.50, p<0.05\right)$. In addition, positive linear relationships for vendace and pike were near the significance limit (vendace adj. $\mathrm{r}^{2}=0.28, p=0.067$; pike adj. $\left.r^{2}=0.22 p=0.052\right)$. THg bioaccumulation rate relative to age displayed a positive linear relationship with PC1 for whitefish (adj. $\left.r^{2}=0.72, p<0.005\right)$ and pike (adj. $\left.r^{2}=0.40, p<0.01\right)$. A non-linear relationship between $\mathrm{THg}$ bioaccumulation rate relative to age and PC1 was evident for perch $\left(\operatorname{adj} . r^{2}=0.64, p<0.005\right)$ and ruffe $\left(\operatorname{adj} . r^{2}=0.50, p<0.05\right)$ (Table 3, Fig. 3). For vendace, the linear relationship was close to being considered significant at the $p=0.05$ level (adj. $r^{2}=0.41, p=0.053$ ).

Bioaccumulation rate of THg relative to length for vendace (adj. $r^{2}=0.50, p<0.05$ ) and perch $\left(\operatorname{adj} . r^{2}=0.55, p<0.01\right)$, and relative to age for pike (adj. $\left.r^{2}=0.23, p<0.05\right)$ (Table 3, Fig. S14) were positively related to lake PC3 score. Moreover, the relationship of PC3 with the bioaccumulation rate relative to age was near the significance limit for vendace $\left(\operatorname{adj} . r^{2}=0.32, p=0.085\right)$ and perch (adj. $\left.r^{2}=0.23, p=0.066\right)$, as well as relative to length for pike (adj. $\left.r^{2}=0.22, p=0.054\right)$. 


\section{DISCUSSION}

\subsection{Main results}

Increased THg tissue concentration was found in lakes of warmer climate and increased productivity for most species. Adjusted tissue THg concentrations had significant and steep positive slopes with lake climate-productivity (PC1) for perch and pike. Shallower, but still significant, slopes were observed for vendace and roach, whilst no significant relationships were found for whitefish and ruffe. An increasing THg bioaccumulation rate from north to south was not as robustly supported statistically for warmer and more productive lakes. However, our results showed significant positive slopes between $\mathrm{THg}$ bioaccumulation rate and PC1 for whitefish and pike, as well as $\mathrm{u}$-shaped relationships for perch and ruffe. Higher THg bioaccumulation rates were related to increasing catchment magnitude (PC3) for vendace, perch, and pike, whereas no relationship between $\mathrm{THg}$ concentration or bioaccumulation rate and lake morphometry (PC2) was found for any species.

\subsection{THg concentration links to warming and eutrophication of Subarctic lakes}

Combined effects of changing climate-productivity and catchment land use in the Subarctic study lakes was correlated with significantly elevated THg concentrations of several fish species. Foraging guilds of our study fish species encompassed the full suite of foraging strategies evident in these systems, ranging from top predator pike and mesopredator large perch to pelagic zooplanktivore vendace and small roach and perch, as well as benthic invertivores whitefish and ruffe. The highest increase in THg concentrations (i.e. the slope of the regression between THg and PC1) along the study gradient were found for pike (length: 0.108; age: 0.104) and perch (length: 0.126; age: 0.102), whereas lower increases were found for vendace (age: 0.078) and roach (length: 0.093; age: 0.083). Moreover, ruffe and whitefish were lacking significant trends. Previous studies 
have shown that higher THg levels in fish are connected to increasing trophic level of fish (e.g. Jernelöv and Lann, 1971; Lavoie et al., 2013), as well as the reliance on pelagic rather than littoral benthic food web (Power et al. 2002; Thomas et al., 2016; Kahilainen et al., 2017). Thus, the foraging habitat and the trophic level of species likely influenced the observed trends in the mercury concentrations.

The eutrophication trend of the study lakes, seen as increasing phosphorus and nitrogen concentration and decreasing compensation depth, is evidently caused by joint effects of increasing temperature and precipitation together with intensifying forestry practices, i.e. clear cutting, site preparation and ditching (Jussila et al., 2014), while the proportion of agriculture in the catchments is very low $(<1 \%)$. The ultimate source of eutrophication is likely important as sewage and agriculture related eutrophication usually cause dilution of THg in fish muscle, whereas forestry related eutrophication seems to have opposite effect (Sonesten, 2003b). Advancing spring thaw due to temperature rise together with increasing precipitation and human-modified catchments enhance the mobility of organic carbon and direct leaching of DOC and Hg to lakes (Stern et al., 2012). The combination of warming lakes and increasing decomposition of DOC enhance lowoxygen conditions suitable for bacterial methylation of $\mathrm{Hg}$ in both terrestrial and lake ecosystems (Evans et al., 2005a, b; Lehnherr, 2014; Yang et al., 2016). Over six-fold decrease in compensation depth from north to lower latitudes likely relates to decreasing oxygen levels and elevating $\mathrm{Hg}$ methylation activity.

The proportion of forested watershed (from 2 to $16 \%$ ) and artificial ditch kilometers (from 0 to $6.67 \mathrm{~km} / \mathrm{km}^{2}$ ) in the lake catchment both increase towards lower latitudes with simultaneously increasing THg concentrations of four out of six fish species studied. Despite the increasing forested proportion and ditching length, the increase of tree volume $\left(\mathrm{m}^{3} \mathrm{ha}^{-1}\right)$ in the catchment stopped below the mesotrophic study lakes, and has decreased due to extensive clear-cuts in the southern 
404 limits of the study region (Jussila et al., 2014). These trends strongly suggest a positive connection 405 between land-use and $\mathrm{Hg}$ concentrations in fish. Previous studies have shown that forested 406 peatland catchments and intensified forestry elevate THg concentrations in lake communities and 407 fish (Sonesten, 2003b; Garcia and Carignan, 2005). Forested watersheds and forestry practices 408 increase the load of nutrients, organic matter and $\mathrm{Hg}$ to lakes, as well as elevate $\mathrm{Hg}$ methylation 409 both in the catchment and lakes (Porvari et al., 2003; Skyllberg et al., 2009; Kronberg et al., 2016a, 410 b). Such effects of increasing direct leaching of $\mathrm{Hg}$, as well as higher methylation activity due to 411 decomposition of DOC have likely contributed to the increasing fish THg concentrations in our study 412 lakes. The effects of forestry practices on THg in the water and biota are also highly dependent on 413 the forestry operation methods, the cutting season, morphometric characteristics (e.g. slope) of the catchment area, and type of bedrock, complicating the development of robust forestry and water 415 THg concentration relationships at the landscape level (Rask et al., 1998; Eklöf et al., 2014; Kronberg et al., 2016a; Ukonmaanaho et al., 2016).

In addition to direct leaching of mercury from clear-cut sites, it is likely that increasing temperature and productivity cause a shift in basal energy sources and have a role in elevated fish THg concentrations. Here, benthic-driven primary production typically dominates in cold oligotrophic lakes, where the pelagic zooplankton have only a single short peak during the mid to 421 late summer (Kahilainen et al., 2003, 2005; Hayden et al., 2014b). In warmer and more productive 422 lakes, the proportion of benthic primary production decreased along as a function of shading and nutrient competition by pelagic phytoplankton and bacterial production (Vadeboncoeur et al., 2003;

424 Karlsson et al., 2009). Such effect is evident also in our lakes, where compensation depth decreased 425 from $10 \mathrm{~m}$ in the northernmost lakes to $1.5 \mathrm{~m}$ in the southernmost lakes with a simultaneous 426 increase in nutrient levels. Previous studies have found much higher THg concentrations in pelagic 427 fish than benthic fish in Subarctic lakes (Power et al., 2002; Thomas et al., 2016; Kahilainen et al., 
2017). In the Subarctic lakes, littoral benthic macroinvertebrates have generally lower mercury content than zooplankton explaining the low THg concentration in benthivorous fish, such as whitefish and ruffe in the study lakes (Kahilainen et al., 2016, 2017; Keva et al., 2017). Zooplanktivores, such as vendace, small roach, and perch, as well as piscivorous fish (pike, large perch) feeding on these pelagic forage fish are often THg enriched (Thomas et al., 2016). However, these foraging guild related THg concentrations are not directly correlated with trends in bioaccumulation rates.

\subsection{Links between $\mathrm{THg}$ bioaccumulation rate and climate-productivity}

THg bioaccumulation rate (the slope of regression between THg and length or age) of whitefish and pike displayed a positive linear relationship with climate-productivity of lakes. However, ushaped, non-linear relationships were observed for perch and ruffe, with the lowest THg bioaccumulation rate in the mesotrophic lakes. Changes in the THg bioaccumulation rate are less straight-forward than what was seen with THg concentrations, due to shifts in energy source towards pelagic and fish community structure along the lake gradient (Vadeboncouer et al. 2003; Thomas et al., 2016; Hayden et al., 2017).

For whitefish, THg bioaccumulation relative to length was negative in the northernmost lakes, whereas in more productive lakes bioaccumulation was positive. This change in the direction of the regression resulted in a positive relationship between bioaccumulation rate and lake climateproductivity in the full data. The increasing THg bioaccumulation rate of whitefish southward the climate-productivity gradient is likely related to changes in foraging habitats. In the northernmost oligotrophic lakes, whitefish use pelagic zooplankton mainly in juvenile phase and typically shift to littoral benthic invertebrates in later life stages (Kahilainen et al., 2003). Such ontogenetic diet shifts from THg rich pelagic zooplankton towards THg poor littoral benthic macroinvertebrates evidently 
reduces the bioaccumulation rate of mercury (Kahilainen et al., 2017). However, whitefish populations in the southern lakes do not demonstrate this ontogenetic shift and continue to feed upon pelagic zooplankton (Heikinheimo et al., 2000), and this ontogenetic change in foraging habitats could be seen in the changing bioaccumulation trends along our study lakes.

THg bioaccumulation rate is increasing for pike in the studied lake gradient from north to south, which is probably related to changes in prey species composition in lower trophic levels, seen as a shift in fish dominance from salmonids to percids and cyprinids toward lower latitudes (Hayden et al., 2017). Pike and other piscivorous fish usually consume the most abundant and easily available prey fish in Subarctic lakes (Kahilainen and Lehtonen 2003). A diet shift of pike and large perch from benthivorous whitefish with relatively low and stable THg concentrations (Hayden et al., 2013; Hayden et al. 2014a; Kahilainen et al., 2017) to other species such as perch, vendace or roach that have increasing THg concentrations from north to south, would likely increase THg bioaccumulation rate of piscivorous pike as well as large perch. Furthermore, larger individuals of aforementioned prey species contained higher THg concentrations that is also important, as prey size of piscivores generally increases with length (Kahilainen and Lehtonen, 2003). Increasing food-chain length towards warmer and eutrophic lakes due to additional pelagic species in lower latitudes (Hayden et al., 2014b; Thomas et al. 2016; Hayden et al., 2017) would also contribute to the higher THg bioaccumulation rate especially in apex predators (pike and large perch).

Vendace, perch, and ruffe did not show evidence of significant linear relationships between THg bioaccumulation rate and lake climate-productivity. However, data revealed u-shaped non-linear relationships for perch and ruffe, with lowest bioaccumulation rate in the mesotrophic lakes. THg concentrations of most fish species increased toward warmer and eutrophic lakes, but the rate of THg bioaccumulation relative to length and age should not be affected, if the growth rate and the THg levels of prey items remained stable. In addition, within the climate and productivity gradients 
from north to south in the study region, a slight increase in temperature and productivity to a moderate level may increase the growth rate of the study species and lead to growth dilution of THg in fish muscle (Simoneau et al., 2005; Hayden et al., 2014a, 2017). This phenomenon is likely responsible for the u-shaped relationships observed for perch and ruffe.

Positive relationships between THg bioaccumulation rate and catchment magnitude (PC3), referring principally to the size of the catchment, were significant for vendace, perch, and pike. However, PC3 axis explained only $13 \%$, of the variation between lakes, considerably less than either PC1 or PC2. Moreover, the PC3 score of Lake Vaatto (lake number 17 in Fig. 1), a large and completely ditched catchment, is clearly different from the other lakes and likely driving significant relationships for the fish species. Since all the other lakes are rather similar with regard to the relative catchment size, caution should be taken when interpreting any possible relationship between PC3 scores and THg bioaccumulation rate, despite the statistically significant regression.

\subsection{Human health considerations}

High mercury exposure to humans has been linked to damage in neurological, reproductive, immune, and cardiovascular systems (Mergler et al., 2007). The maximum acceptable level set by United Nations (Codex Alimentarius, 1995) of THg in fish muscle tissue for human diet is $0.5 \mu \mathrm{g} \mathrm{g}^{-1}$ wet mass for non-piscivorous fish (all study species except pike) and $1 \mu \mathrm{g} \mathrm{g}^{-1}$ for predatory fish (e.g. pike) that corresponds to approximately $2.5-5 \mu \mathrm{g} \mathrm{g}^{-1}$ dry mass. Most of the fish species sampled in this current study had THg concentrations below these international health limits, except for a few individual predator perch $(n=4)$ and pike $(n=4)$. The fish with the highest THg concentrations were typically large, old, and located in the most eutrophic and warmest lakes. Thus, local people consuming fishes in the southern lakes, especially pike and perch that are target species of subsistence and recreational fishing, have a higher risk of exposure to $\mathrm{THg}$ relative to people 
consuming fishes caught in northern lakes, where whitefish is the target species (Thomas et al., 2016; Kahilainen et al., 2017; Keva et al., 2017). More attention should also be paid to the fact, that fish consumption in the Arctic and Subarctic, e.g. by indigenous Sami people, is generally higher than in lower latitudes and most of the consumption is locally derived fish (Sjölander, 2011). Generally, the increasing THg concentrations of important subsistence fishery species (vendace, perch, and pike) along the climate-productivity gradient of this study from north to south, adds further evidence of adverse effects of eutrophication on the quality of fish as a human diet resource (Taipale et al., 2016).

\section{CONCLUSIONS}

This study revealed a positive linear relationship between adjusted THg concentration in fish and increasing climate-productivity values of Subarctic lakes for several fish species. Results indicated that lake eutrophication due to climatic change and intensification of forestry related land use activities have joint effects, elevating THg concentrations in several fish species. Accelerating THg bioaccumulation rate towards warmer and more productive lakes was evident for whitefish and pike, whereas a u-shaped relationship was found for perch and ruffe, indicating that a minor increase in lake temperature and trophic state might lead to growth dilution of $\mathrm{Hg}$ for some fish species, whereas loss of clarity and eutrophication lead to elevated THg burden. As evident in the study, $\mathrm{THg}$ bioaccumulation and dynamics are both species-specific and lake-specific, and thus the results should be interpreted along the full lake gradient from north to south for each species. Combined effects of climate and land use are highly complex, altering both abiotic and biotic factors in each lake and catchment, and need to be considered in future THg studies of fish. Generally, there is evident need for future studies that examine entire food webs, revealing the pelagic and benthic contributions of $\mathrm{THg}$ sources and subsequent biomagnification patterns along climatic and 
productivity gradients. Such baseline studies are critical for a selection of lakes in the long-term monitoring studies of $\mathrm{THg}$ concentrations in the rapidly changing Subarctic.

\section{ACKNOWLEDGEMENTS}

We would like to thank all people participating to field and laboratory work during all these years. Kilpisjärvi Biological Station and Nuottavaara Village Association kindly provided facilities during the field sampling. Financement was received from Academy of Finland (projects 1140903, 1268566 to KKK), as well as Maa- ja vesitekniikan tuki ry, Vanamo ry, and Ympäristön ystävät foundation by Alumni ry to SAA. We thank four anonymous referees for their constructive comments on our manuscript.

\section{REFERENCES}

AMAP, 2011. Arctic Assessment 2011: Mercury in the Arctic. Arctic Monitoring and Assessment Programme (AMAP), Oslo, Norway.

Bates, B.C., Kundzewicz, Z.W., Wu, S., Palutikof, J.P., 2008. Climate Change and Water. Technical Paper of the Intergovernmental Panel on Climate Change, IPCC Secretariat, Geneva, 210 pp.

Bodaly, R.A., Rudd, J.W.M., Fudge, R.J.P., Kelly, C.A., 1993. Mercury concentrations in fish related to size of remote Canadian Shield lakes. Can. J. Fish. Aquat. Sci. 50, 980-987.

Braaten, H.F.V., Åkerblom, S., de Wit, H.A., Skotte, G., Rask, M., Vuorenmaa, J., Kahilainen, K.K., Malinen, T., Rognerud, S., Lydersen, E., Amundsen, P.-A., Kashulin, N., Kashulina, T., Terentyev, P., Christensen, G., Jackson-Blake, L., Lund, E., Rosseland, B.E., 2017. Spatial and temporal trends of mercury in freshwater fish in Fennoscandia (1965-2015). ICP Waters report 132/2017. Norwegian Institute for Water Research, Oslo, Norway.

Bravo, A.G., Bouchet, S., Tolu, J., Björn, E., Mateos-Rivera, A., Bertilsson, S., 2017. Molecular composition of organic matter controls methylmercury formation in boreal lakes. Nat. Commun. 8, 14255.

Cabana, G., Rasmussen, J.B., 1994. Modelling food chain structure and contaminant bioaccumulation using stable nitrogen isotopes. Nature 372, 255-257.

Canário, J., Branco, V., Vale, C., 2007. Seasonal variation of monomethylmercury concentrations in surface sediments of the Tagus Estuary (Portugal). Environ. Pollut. 148, 380-383.

Casselman, J.M., Lewis, C.A., 1996. Habitat requirements of northern pike (Esox lucius). Can. J. Fish. Aquat. Sci. 53, 161-174. 
Chen, C.Y., Stemberger, R.S., Kamman, N.C., Mayes, B.M., Folt, C.L., 2005. Patterns of Hg bioaccumulation and transfer in aquatic food webs across multi-lake studies in the Northeast US. Ecotoxicology 14, 135-147.

Chen, J., Pehkonen, S.O., Lin, C.-J., 2003. Degradation of monomethylmercury chloride by hydroxyl radicals in simulated natural waters. Water Res. 37, 2496-2504.

Codex Alimentarius, 1995. Codex general standard for contaminants and toxins in food and feed. Codex Alimentarius. Codex Standard 193-1995. Geneva: Food Agricultural Organisation of the United Nations, World Health Organisation (FAO/WHO) Joint Publications. Retrieved in July 2016: http://www.fao.org/input/download/standards/17/CXS_193e_2015.pdf

de Wit, H.A., Granhus, A., Lindholm, M., Kainz, M.J., Lin, Y., Braaten, H.F.V., Blaszczak, J., 2014. Forest harvest effects on mercury in streams and biota in Norwegian boreal catchments. Forest Ecol. Manag. 324, 52-63.

Eckley, C.S., Hintelmann, H., 2006. Determination of mercury methylation potentials in the water column of lakes across Canada. Sci. Total Environ. 368, 111-125.

Eklöf, K., Schelker, J., Sørensen, R., Meili, M., Laudon, H., von Brömssen, C., Bishop, K., 2014. Impact of forestry on total and methyl-mercury in surface waters: distinguishing effects of logging and site preparation. Env. Sci. Technol. 48, 4690-4698.

Evans, M.S., Lockhart, L., Doetzel, L., Low, G., Muir, D., Kidd, K.A., Stephens, G., Delaronde, J., $2005 a$. Elevated mercury concentrations in fish in lakes in the Mackenzie River Basin: the role of physical, chemical, and biological factors. Sci. Total Environ. 351-352, 479-500.

Evans, M.S., Muir, D., Lockhart, L., Stern, G., Ryan, M., Roach, P., 2005. Persistent organic pollutants and metals in the freshwater biota of the Canadian Subarctic and Arctic: an overview. Sci. Total Environ. 351-352, 94-147.

Garcia, E., Carignan, R., 2005. Mercury concentrations in fish from forest harvesting and fireimpacted Canadian boreal lakes compared using stable isotopes of nitrogen. Environ. Toxicol. Chem. 24, 685-693.

Gordon, T.A.C., Harding, H.R., Clever, F.K., Davidson, I.K., Davidson, W., Montgomery, D.W. et al., 2018. Fishes in changing world: learning from the past to promote sustainability of fish populations. J. Fish Biol. 92, 804-827.

Grigal, D.F., 2002. Inputs and outputs of mercury from terrestrial watersheds: a review. Environ. Rev. 10, 1-39.

Hall, B.D., Bodaly, R.A., Fudge, R.J.P., Rudd, J.W.M., Rosenberg, D.M., 1997. Food as the dominant pathway of methylmercury uptake by fish. Water Air Soil Pollut. 100, 13-24.

Harrod, C., Mallela, J., Kahilainen, K.K., 2010. Phenotype-environment correlations in a putative whitefish adaptive radiation. J. Animal Ecol. 79, 1057-1068.

Hayden, B., Holopainen, T., Amundsen, P.-A., Eloranta, A.P., Knudsen, R., Præbel, K., Kahilainen, K.K., 2013. Interactions between invading benthivores and native whitefish in subarctic lakes. Freshw. Biol. 58, 1234-1250.

Hayden, B. Harrod, C., Kahilainen, K.K., 2014a. Lake morphometry and resource polymorphism determine niche segregation between cool and cold-water adapted fish. Ecology 95, 538-552.

Hayden, B., Harrod, C., Kahilainen, K.K., 2014b. Dual fuels: intra-annual variation in the relative importance of benthic and pelagic resources to maintenance, growth and reproduction in a generalist salmonid fish. J. Animal Ecol. 83, 1501-1512. 
Hayden, B., Harrod, C., Sonninen, E., Kahilainen, K.K., 2015. Seasonal depletion of resources intensifies trophic interactions in subarctic freshwater fish communities. Freshw. Biol. 60, 1000-1015.

Hayden, B., Myllykangas, J.-P., Rolls, R., Kahilainen, K.K., 2017. Climate and productivity shape fish and invertebrate community structure in subarctic lakes. Freshw. Biol. 62, 990-1003.

Heikinheimo, O., Miinalainen, M., Peltonen, H. 2000. Diet, growth and competitive abilities of sympatric whitefish forms in a dense introduced population: results of stocking experiment. J. Fish Biol. 57, 808-827.

Huntington, H.P., Boyle, M., Flowers, G.E., Weatherly, J.W., Hamilton, L.C., Hinzman, H., Gerlach, C., Zulueta, R., Nicolson, C., Overpeck, J., 2007. The influence of human activity in the Arctic on climate and climate impacts. Climate Change 82, 77-92.

IPCC, 2015. Climate Change 2014: Synthesis Report. Contribution of Working Groups I, II and III to the Fifth Assessment Report of the Intergovernmental Panel on Climate Change. Geneva, Switzerland.

Jernelöv, A., Lann, H., 1971. Mercury accumulation in food chains. Oikos 22, 403-406.

Jussila M., Liljaniemi P., Karvonen L., Johansson M., 2014. Water protection in regeneration cutting and site preparation areas. Guidelines and practices in the field. Centre for Economic Development, Transport, and the Environment for Lapland 72, 1-36.

Kahilainen, K., Lehtonen, H., 2003. Piscivory and prey selection of four predator species in a whitefish dominated subarctic lake. J. Fish Biol. 63, 659-672.

Kahilainen, K., Lehtonen, H., Könönen, K., 2003. Consequence of habitat segregation to growth rate of two sparsely rakered whitefish forms (Coregonus lavaretus (L.)) in a subarctic lake. Ecol. Freshw. Fish 12, 275-285.

Kahilainen, K., Østbye, K., 2006: Morphological differentiation and resource polymorphism in three sympatric whitefish Coregonus lavaretus (L.) forms in a subarctic lake. J. Fish Biol. 68, 63-79.

Kahilainen, K., Alajärvi, E., Lehtonen, H. 2005. Planktivory and diet-overlap of densely rakered whitefish (Coregonus lavaretus (L.)) in a subarctic lake. Ecol. Freshw. Fish 14, 50-58.

Kahilainen, K.K., Siwertsson, A., Gjelland, K.Ø. Knudsen, R., Bøhn, T., Amundsen, P-A., 2011a. The role of gill raker number variability in adaptive radiation of coregonid fish. Evol. Ecol. 25, 573588.

Kahilainen, K.K., Østbye, K., Harrod, C., Shikano, T., Malinen, T., Merilä, J., 2011b. Species introduction promotes hybridization and introgression in Coregonus: is there sign of selection against hybrids? Mol. Ecol. 20, 3838-3855.

Kahilainen, K.K., Thomas, S.M., Keva, O., Hayden, B., Knudsen, R., Eloranta, A.P., Tuohiluoto, K., Amundsen, P-A., Malinen, T., Järvinen, A., 2016. Seasonal dietary shift to zooplankton influences stable isotope ratios and total mercury concentrations in Arctic charr (Salvelinus alpinus (L.)). Hydrobiologia 783, 47-63.

Kahilainen, K.K., Thomas, S.M., Nystedt, E.K.M., Keva, O., Malinen, T., Hayden, B., 2017. Ecomorphological divergence drives differential mercury bioaccumulation of polymorphic European whitefish (Coregonus lavaretus) populations of subarctic lakes. Sci. Total Env. 599600, 1768-1778.

Karimi, R., Chen, C.Y., Folt, C.L., 2016. Comparing nearshore benthic and pelagic prey as mercury sources to lake fish: The importance of prey quality and mercury content. Sci. Total Environ. $565,211-221$. 
Karlsson, J., Byström, P., Ask, J., Ask, P., Persson, L., Jansson, M., 2009. Light limitation of nutrientpoor lake ecosystems. Nature 460, 506-509.

Keva, O., Hayden, B., Harrod, C., Kahilainen, K.K., 2017. Total mercury concentrations in liver and muscle of European whitefish (Coregonus lavaretus (L.)) in a subarctic lake - Assessing the factors driving year-round variation. Environ. Poll. 231, 1518-1528.

Kidd, K.A., Muir, D.C.G., Evans, M.S., Wang, X., Whittle, M., Swanson, H.K., Johnston, T., Guildford, S., 2012. Biomagnification of mercury through lake trout (Salvelinus namaycush) food webs of lakes with different physical, chemical and biological characteristics. Sci. Total Environ. 438, 135-143.

Klapstein, S.J., Ziegler, S.E., O'Driscoll, N.J., 2018. Methylmercury photodemethylation is inhibited in lakes with high dissolved organic matter. Environ. Poll. 232, 392-401.

Klein Tank, A.M.G., et al., 2002. Daily dataset of 20th-century surface air temperature and precipitation series for the European Climate Assessment. Int. J. of Climatol. 22, 1441-1453.

Kronberg, R.-M., Drott, A., Jiskra, M., Wiederhold, J.G., Björn, E., Skyllberg, U., 2016a. Forest harvest contribution to Boreal freshwater methyl mercury load. Global Biogeoch. Cycles 30, 825-843.

Kronberg, R.-M., Jiskra, M., Wiederhold, J.G., Björn, E., Skyllberg, U., 2016b. Methyl mercury formation in hillslope soils of boreal forests: The role of forest harvest and anaerobic microbes. Environ. Sci. Technol. 50, 9177-9186.

Lavoie R.A., Jardine T.D., Chumchal M.M., Kidd K.A., Campbell L.M., 2013. Biomagnification of mercury in aquatic food webs: A worldwide meta-analysis. Environ. Sci. Technol. 47, 338513394.

Lehnherr, I., 2014. Methylmercury biogeochemistry: A review with special reference to Arctic aquatic ecosystems. Environ. Rev. 243, 1-70.

Leppänen, J., Siitonen, S., Weckström, J., 2017. The stability of Cladoceran communities in sub-Arctic NW Finnish Lapland lakes. Polar Biol. 40, 2211-2223.

Madenjian, C., Ebener, M., Krabbenhoft, D., 2016. Mercury accumulation, and the mercury-PCB-sex interaction, in lake whitefish (Coregonus clupeaformis). Environments 3, 7.

Magnuson, J.J., Crowder, L.B., Medvick, P.A., 1979. Temperature as an ecological resource. Amer. Zool. 19, 331-343.

Mergler, D., Anderson, H.A., Hing, L.M.C., Mahaffey, K.R., Murray, M., Sakamoto, M., Stern, A.H., 2007. Methylmercury exposure and health effects in humans: a worldwide concern. Ambio 36, 3-11.

Morel, F.M.M., Kraepiel, A.M.L., Amyot, M., 1998. The chemical cycle and bioaccumulation of mercury. Annu. Rev. Ecol. Syst. 29, 543-566.

Nieminen, M., Koskinen, M., Sarkkola, S., Laurén, A., Kaila, A., Kiikkilä, O., Nieminen, T.M., Ukonmaanaho, L., 2015. Dissolved organic carbon export from harvested peatland forests with differing site characteristics. Water Air Soil Poll. 226, 181.

Pacyna, E.G., Pacyna, J.M., Sundseth, K., Munthe, J., Kindbom, K., Wilson, S., Steenhuisen, F., Maxson, P., 2010. Global emission of mercury to the atmosphere from anthropogenic sources in 2005 and projections to 2020. Atmos. Environ. 44, 2487-2499.

Pickhardt, P.C., Fisher, N.S., 2007. Accumulation of inorganic and methylmecury by freshwater phytoplankton in two contrasting water bodies. Environ. Sci. Technol. 41, 125-131.

Porvari, P., Verta, M., 2003. Total and methyl mercury concentrations and fluxes from small boreal forest catchments in Finland. Environ. Poll. 123, 181-191. 
Porvari, P., Verta, M., Munthe, J., Haapanen, M., 2003. Forestry Practices Increase Mercury and Methyl Mercury Output from Boreal Forest Catchments. Environ. Sci. Technol. 37, 2389-2393.

Power, M., Klein, G.M., Guiguer, K.R.R.A., Kwan, M.K.H., 2002. Mercury accumulation in the fish community of a sub-Arctic lake in relation to trophic position and carbon sources. J. Appl. Ecol. 39, 819-830.

R Core Team, 2017. R: A language and environment for statistical computing. R Foundation for Statistical Computing, Vienna, Austria. URL https://www.R-project.org/.

Rask, M., Nyberg, K., Markkanen, S.-L., Ojala, A., 1998. Forestry in catchments: Effects on water quality, plankton, zoobenthos and fish in small lakes. Boreal Environ. Res. 3, 75-86.

Rolls, R.J., Hayden, B., Kahilainen, K.K., 2017. Conceptualising the interactive effects of climate change and biological invasions on subarctic freshwater fish. Ecol. Evol. 7: 4109-4128.

Rydberg, J., Karlsson, J., Nyman, R., Wanhatalo, I., Näthe, K., Bindler, R., 2010. Importance of vegetation type for mercury sequestration in the northern Swedish mire, Rödmossamyran. Geochim. Cosmochim. Acta 74, 7116-7126.

Sarkkola, S., Koivusalo, H., Laurén, A., Kortelainen, P., Mattsson, T., Palviainen, M., Piirainen, S., Starr, M., Finér, L., 2009. Trends in hydrometeorological conditions and stream water organic carbon in boreal forested catchments. Sci. Total Environ. 408, 92-101.

Schroeder, W.H., Munthe, J., 1998. Atmospheric mercury - an overview. Atmos. Environ. 32, 809822.

Serreze, M.C., Walsh, J.E., Chapin, F.S.I., Osterkamp, T., Dyurgerov, M., Romanovsky, V., Oechel, W.C., Morison, J., Zhang, T., Barry, R.G., 2000. Observational evidence of recent change in the northern high-latitude environment. Climate Change 46, 159-207.

Simoneau M., Lucotte M., Garceau S., Laliberté D., 2005. Fish growth rates modulate mercury concentrations in walleye (Sander vitreus) from eastern Canadian lakes. Environ. Res. 98, 7382.

Sjölander, P., 2011. What is known about the health and living conditions of the indigenous people of northern Scandinavia, the Sami? Global Health Action 4, 8457.

Skyllberg, U., Westin, M.B., Meili, M., Björn, E., 2009. Elevated concentrations of methyl mercury in streams after forest clear-cut: a consequence of mobilization from soil or new methylation? Environ. Sci. Technol. 43, 8535-8541.

Sonesten, L., 2003a. Fish mercury levels in lakes-adjusting for $\mathrm{Hg}$ and fish-size covariation. Environ. Poll. 125, 255-265.

Sonesten, L., 2003b. Catchment area composition and water chemistry heavily affects mercury levels in perch (Perca fluviatilis L.). Water Air Soil Poll. 144, 117-139.

Stern, G.A., Macdonald, R.W., Outridge, P.M., Wilson, S., Chételat, J., Cole, A., Hintelmann, H., Loseto, L.L., Steffen, A., Wang, F., Zdanowicz, C., 2012. How does climate change influence arctic mercury? Sci. Total Environ. 414, 22-42.

Taipale, S.J., Vuorio, K., Strandberg, U. Kahilainen, K.K., Järvinen, M., Hiltunen, M., Peltomaa, E., Kankaala, P., 2016. Lake eutrophication and brownification downgrade availability and transfer of essential fatty acids for human consumption. Environ. Int. 96, 156-166.

Thomas, S.M., Kiljunen, M., Malinen, T., Eloranta, A.P., Amundsen, P.-A., Lodenius, M., Kahilainen, K.K., 2016. Food-web structure and mercury dynamics in a large subarctic lake following multiple species introductions. Freshw. Biol. 61, 500-517. 
Trudel, M., Rasmussen, J.B., 2006. Bioenergetics and mercury dynamics in fish: a modelling perspective. Can. J. Fish. Aquat. Sci. 63, 1890-1902.

Ukonmaanaho, L., Starr, M., Kantola, M., Laurén, A., Piispanen, J., Pietilä, H., Perämäki, P., Merilä, P., Fritze, H., Tuomivirta, T., Heikkinen, J., Mäkinen, J., Nieminen, T.M., 2016. Impacts of forest harvesting on mobilization of $\mathrm{Hg}$ and $\mathrm{MeHg}$ in drained peatland forests on black schist or felsic bedrock. Environ. Monit. Assess. 188, 228.

Ullrich, S., Tantom, T.W., Abdrashitova, S., 2001. Mercury in the aquatic environment: a review of factors affecting methylation. Crit. Rev. Environ. Sci. Technol. 31, 241-293.

UNEP, 2013. Global Mercury Assessment 2013: Sources, Emissions, Releases and Environmental Transport. Geneva, Switzerland.

Vadeboncouer, Y., Jeppesen, E., Vander Zanden, M.J., Schierup, H.-H., Christoffersen, K., Lodge, D.M., 2003. From Greenland to green lakes: Cultural eutrophication and the loss of benthic pathways in lakes. Limnol. Oceanogr. 48, 1408-1418.

Watras, C.J., Back, R.C., Halvorsen, S., Hudson, R.J.M., Morrison, K.A., Wente, S.P., 1998. Bioaccumulation of mercury in pelagic freshwater food webs. Sci. Total Environ. 219, 183208.

Wrona F., Reist J., Amundsen P.-A., Chambers P.A., Christoffersen K., Culp J.M., et al., 2013. Freshwater Ecosystems. In: Arctic Biodiversity Assessment. pp. 442-485. Conservation of Arctic Flora and Flora. Akureyri.

Yang, Z., Fang, W., Lu, X., Sheng, G.P., Graham, D.E., Liang, L., Wullschleger, S.D., Gu, B., 2016. Warming increases methylmercury production in an Arctic soil. Environ. Pollut. 214, 504-509. 

67

TABLES

Table 1. Study lakes and selected environmental variables used in principal component analyses (PCA). Altitude (Alt), mean precipitation (Precip) and air temperature (Air temp) in open-water season (June-September 1981-2010), total phosphorus (TP), compensation (Comp) and mean (Mean) depths, lake volume (LV), lake area (LA), catchment area (CA), forest (For) and wetland (Wet) percentages in the catchment area, ditching length $(\mathrm{km})$ per $1 \mathrm{~km}^{2}$ of catchment area (Ditch), tree volume (TV) per hectare of forested and wetland area, catchment-lake area ratio (CA:LA). PCA scores for each lake representing climate and productivity (PC1), lake morphometry (PC2), and catchment magnitude (PC3). Please note that lakes (column No) are ordered by PC1 scores. 61 2 63 64 65 66 


\begin{tabular}{|c|c|c|c|c|c|c|c|c|c|c|c|c|c|c|c|c|c|c|}
\hline No & Lake & $\begin{array}{r}\text { Alt } \\
\text { (m a.s.l) }\end{array}$ & $\begin{array}{l}\text { Precip } \\
(\mathrm{mm})\end{array}$ & $\begin{array}{r}\text { Air temp } \\
\left({ }^{\circ} \mathrm{C}\right)\end{array}$ & $\begin{array}{r}T P \\
(\mu \mathrm{g} / \mathrm{L})\end{array}$ & $\begin{array}{l}\text { De } \\
\text { Comp }\end{array}$ & $\begin{array}{l}\text { th }(m) \\
\text { Mean }\end{array}$ & $\begin{array}{r}\text { LV } \\
\left(\mathrm{milj}^{3}\right)^{3}\end{array}$ & $\begin{array}{r}\mathrm{LA} \\
\left(\mathrm{km}^{2}\right)\end{array}$ & $\begin{array}{r}\text { CA } \\
\left(\mathrm{km}^{2}\right)\end{array}$ & $\begin{array}{l}\text { For } \\
\text { (\%) }\end{array}$ & $\begin{array}{r}\text { Wet } \\
(\%)\end{array}$ & $\begin{array}{r}\text { Ditch } \\
\left(\mathrm{km} / \mathrm{km}^{2}\right)\end{array}$ & $\begin{array}{r}\text { TV } \\
\left(\mathrm{m}^{3} / \mathrm{ha}\right)\end{array}$ & CA:LA & $\begin{array}{r}\text { PC1 } \\
(52 \%)\end{array}$ & $\begin{array}{r}\text { PC2 } \\
(19 \%)\end{array}$ & $\begin{array}{r}\text { PC3 } \\
(13 \%)\end{array}$ \\
\hline 1 & Kilpis & 473 & 197 & 8.4 & 4 & 10 & 19.4 & 728.0 & 37.3 & 260.35 & 8.90 & 4.09 & 0 & 18.66 & 6.98 & 4.91 & -5.62 & -0.54 \\
\hline 2 & Tsahkal & 559 & 197 & 8.4 & 5 & 7.5 & 9 & 10.1 & 1.1 & 28.76 & 2.00 & 5.28 & 0 & 7.01 & 26.15 & 3.77 & 0.63 & 0.16 \\
\hline 3 & Kolta & 490 & 197 & 8.4 & 3 & 9 & 1.1 & 1.4 & 1.3 & 31.04 & 6.90 & 4.00 & 0 & 13.04 & 23.88 & 3.33 & 1.33 & 0.22 \\
\hline 4 & Kuohkima & 489 & 197 & 8.4 & 3 & 8 & 2.6 & 0.8 & 0.3 & 36.17 & 7.10 & 2.60 & 0 & 12.39 & 120.58 & 3.18 & 1.35 & -0.84 \\
\hline 5 & Oiko & 448 & 218 & 8.7 & 7 & 5 & 3.1 & 3.7 & 1.2 & 21.24 & 19.90 & 10.15 & 0 & 20.15 & 17.70 & 2.02 & 1.20 & 0.46 \\
\hline 6 & Kivi & 445 & 221 & 8.7 & 7 & 5 & 2.8 & 9.7 & 3.5 & 165.03 & 4.70 & 15.88 & 0 & 24.23 & 47.15 & 1.99 & 1.11 & -0.60 \\
\hline 7 & Ropi & 399 & 240 & 9 & 10 & 5 & 6.9 & 8.9 & 1.3 & 86.80 & 12.89 & 18.18 & 0 & 23.96 & 66.77 & 1.52 & 0.84 & -0.40 \\
\hline 8 & Palo & 346 & 224 & 9.4 & 21 & 3 & 0.8 & 3.0 & 3.5 & 134.44 & 31.50 & 32.24 & 0.01 & 23.29 & 38.41 & 0.38 & 1.56 & -0.37 \\
\hline 9 & Vaggoval & 331 & 236 & 9.8 & 12 & 4 & 0.5 & 0.8 & 1.8 & 6.03 & 36.03 & 38.99 & 0 & 32.58 & 3.35 & 0.26 & 1.89 & 0.53 \\
\hline 10 & Äkäs & 263 & 256 & 10.5 & 18 & 4.5 & 3 & 39.1 & 13.1 & 74.04 & 56.13 & 12.66 & 0.15 & 81.78 & 5.65 & -1.08 & -0.54 & 1.01 \\
\hline 11 & Jeris & 258 & 256 & 10.5 & 25 & 3.5 & 3.4 & 80.8 & 23.5 & 98.84 & 56.02 & 8.16 & 0.20 & 76.11 & 4.21 & -1.19 & -1.48 & 1.07 \\
\hline 12 & Toras & 247 & 256 & 10.4 & 18 & 3.5 & 3 & 14.7 & 4.9 & 215.34 & 62.30 & 9.90 & 0.14 & 80.55 & 43.95 & -1.47 & -0.17 & -0.05 \\
\hline 13 & Särki & 261 & 256 & 10.5 & 25 & 1.5 & 5.1 & 26.0 & 5 & 14.71 & 58.21 & 4.68 & 0.49 & 74.77 & 2.94 & -1.51 & -0.30 & 1.37 \\
\hline 14 & Särkilompolo & 255 & 256 & 10.5 & 36 & 2.5 & 3.7 & 4.7 & 1.3 & 36.93 & 68.96 & 6.57 & 0.23 & 74.20 & 28.41 & -1.91 & 0.06 & 1.05 \\
\hline 15 & Aalis & 177 & 257 & 11.4 & 45 & 1.5 & 3.2 & 19.3 & 6 & 72.25 & 62.25 & 12.55 & 6.67 & 71.09 & 12.04 & -3.35 & -0.50 & 0.58 \\
\hline 16 & Pasma & 164 & 257 & 11.3 & 48 & 1.5 & 1.6 & 13.0 & 8.4 & 134.63 & 65.03 & 10.59 & 5.70 & 71.45 & 16.03 & -3.45 & -0.57 & 0.41 \\
\hline 17 & Vaatto & 156 & 257 & 11.2 & 30 & 1.5 & 1.8 & 4.2 & 2.3 & 637.97 & 65.03 & 17.28 & 5.62 & 70.45 & 277.38 & -3.62 & -0.24 & -4.96 \\
\hline 18 & Rattos & 118 & 257 & 11.6 & 47 & 1.5 & 2.1 & 8.6 & 4.1 & 58.06 & 72.96 & 4.27 & 5.65 & 78.60 & 14.16 & -3.77 & -0.54 & 0.89 \\
\hline
\end{tabular}


Table 2. Sample sizes $(\mathrm{n})$ and mean, length- and age-adjusted THg concentrations ( $\mu \mathrm{g} \mathrm{g}^{-1}$ dry weight) for whitefish (mean length: $23.4 \mathrm{~cm}$, mean age: 4.7 years, $n=467$ ), vendace (mean length: $13.6 \mathrm{~cm}$, mean age: 3.2 years, $n=283$ ), perch (mean length: $16.4 \mathrm{~cm}$, mean age: 4.6 years, $n=361$ ), pike (mean length: $50.4 \mathrm{~cm}$, mean age: 6.2 years, $\mathrm{n}=312$ ), roach (mean length: $14.1 \mathrm{~cm}$, mean age: 6.2 years, $\mathrm{n}=193$ ) and ruffe (mean length: 9.6 cm, mean age: 4.1 years, $n=409$ ) for each lake. Absence of fish species in the lake is marked as A. Three highest species-specific THgconcentrations for each lake are bolded. Please note that lakes (column No) are ordered by PC1 scores.

\begin{tabular}{|c|c|c|c|c|c|c|c|c|c|c|c|c|c|c|c|c|c|c|c|c|c|c|c|c|c|}
\hline \multirow{2}{*}{\multicolumn{2}{|c|}{ No Lake }} & \multirow{3}{*}{$\begin{array}{l}\mathrm{n} \\
30\end{array}$} & \multicolumn{3}{|c|}{ Whitefish THg } & \multirow{3}{*}{$\frac{n}{A}$} & \multicolumn{3}{|c|}{ Vendace THg } & \multirow{3}{*}{$n$} & \multicolumn{3}{|c|}{ Perch THg } & \multicolumn{4}{|c|}{ Pike THg } & \multicolumn{4}{|c|}{ Roach THg } & \multicolumn{4}{|c|}{ Ruffe THg } \\
\hline & & & mean & length & age & & mean & length & age & & mean & length & age & $n$ & mean & length & age & $n$ & mean & lengtr & age & $\mathrm{n}$ & mean & length & Age \\
\hline 1 & Kilpis & & 0.16 & 0.19 & 0.20 & & - & - & - & & - & - & - & 30 & 0.65 & 0.49 & 0.59 & $A$ & - & - & - & $A$ & - & - & - \\
\hline 2 & Tsahkal & 30 & 0.43 & 0.39 & 0.48 & $A$ & - & - & - & $A$ & - & - & - & $A$ & - & - & - & $A$ & - & - & - & $A$ & - & - & - \\
\hline 3 & Kolta & 30 & 0.18 & 0.17 & 0.18 & A & - & - & - & $A$ & - & - & - & 16 & 0.59 & 0.72 & 0.64 & $A$ & - & - & - & $A$ & - & - & - \\
\hline 1 & Kuohkima & 30 & 0.36 & 0.34 & 0.31 & $A$ & - & - & - & $A$ & - & - & - & 18 & 0.99 & - & - & $A$ & - & - & - & $A$ & - & - & - \\
\hline 5 & Oiko & 30 & 0.47 & 0.46 & 0.47 & $A$ & - & - & - & $A$ & - & - & - & 27 & 1.68 & 1.66 & 1.56 & 1 & - & - & - & 30 & 0.40 & 0.34 & 0.35 \\
\hline 0 & Kivi & 30 & 0.40 & 0.45 & 0.39 & $A$ & - & - & - & 30 & 0.80 & 0.36 & 0.31 & 18 & 1.64 & 1.37 & 1.22 & $A$ & - & - & - & 30 & 0.60 & 0.57 & 0.44 \\
\hline 7 & Ropi & 30 & 0.22 & 0.23 & 0.21 & $A$ & - & - & - & 2 & 0.30 & - & - & 22 & 0.51 & 0.76 & 0.85 & 1 & - & - & - & 21 & 0.51 & 0.53 & 0.44 \\
\hline 8 & Palo & 30 & 0.23 & 0.17 & 0.22 & 30 & 0.24 & 0.19 & 0.29 & 30 & 0.27 & 0.26 & 0.29 & 15 & 0.60 & 0.63 & 0.76 & 5 & 0.30 & - & - & 30 & 0.21 & 0.21 & 0.27 \\
\hline & Vaggoval & 30 & 0.24 & 0.26 & 0.37 & $A$ & - & - & - & 30 & 0.33 & 0.34 & 0.44 & 27 & 0.72 & 0.90 & 0.89 & 1 & - & - & - & 28 & 0.52 & 0.52 & 0.52 \\
\hline & Äkäs & 30 & 0.17 & 0.34 & 0.17 & 30 & 0.28 & 0.29 & 0.29 & 30 & 0.29 & 0.28 & 0.36 & 6 & 0.78 & 0.75 & 1.00 & 30 & 0.21 & 0.23 & 0.21 & 30 & 0.17 & 0.12 & 0.17 \\
\hline & 1 Jeris & 30 & 0.20 & 0.20 & 0.27 & 30 & 0.26 & 0.27 & 0.24 & 30 & 0.25 & 0.31 & 0.43 & 4 & 0.47 & - & - & $A$ & - & - & - & 30 & 0.22 & 0.21 & 0.25 \\
\hline & Toras & 30 & 0.23 & 0.21 & 0.25 & 30 & 0.28 & 0.30 & 0.32 & 30 & 0.31 & 0.35 & 0.38 & 3 & 0.82 & - & - & 30 & 0.42 & 0.40 & 0.41 & 30 & 0.35 & 0.32 & 0.36 \\
\hline & 3 Särki & 30 & 0.21 & 0.19 & 0.24 & 30 & 0.18 & 0.17 & 0.17 & 30 & 0.22 & 0.24 & 0.20 & 1 & - & - & - & A & - & - & - & 30 & 0.15 & 0.11 & 0.16 \\
\hline & - & 30 & 0.16 & 0.14 & 0.15 & 30 & 0.54 & 0.59 & 0.40 & 30 & 0.30 & 0.33 & 0.31 & 17 & 1.20 & 1.24 & 1.31 & 5 & 0.33 & - & 0.32 & 30 & 0.07 & 0.08 & 0.11 \\
\hline & Aalis & A & - & - & - & 30 & 0.46 & 0.57 & 0.45 & 29 & 0.75 & 0.78 & 0.76 & 30 & 1.81 & 1.09 & 1.62 & 30 & 0.37 & 0.37 & 0.38 & 30 & 0.55 & 0.60 & 0.56 \\
\hline & 5 Pasma & 30 & 0.27 & 0.26 & 0.35 & 30 & 0.35 & 0.30 & 0.36 & 30 & 0.59 & 0.61 & 0.60 & 24 & 2.17 & 1.81 & 1.44 & 30 & 0.42 & 0.49 & 0.44 & 30 & 0.27 & 0.36 & 0.32 \\
\hline & Vaatto & 14 & 0.45 & 0.46 & 0.48 & 13 & 0.49 & 0.21 & 0.64 & 30 & 1.03 & 1.07 & 0.91 & 28 & 2.36 & 2.36 & 1.81 & 30 & 0.56 & 0.58 & 0.54 & 30 & 0.48 & 0.55 & 0.43 \\
\hline & 3 Rattos & 3 & 0.26 & - & - & 30 & 0.47 & 0.68 & 0.57 & 30 & 1.01 & 1.08 & 0.92 & 26 & 1.64 & 1.57 & 1.56 & 30 & 0.60 & 0.59 & 0.53 & 30 & 0.39 & 0.57 & 0.40 \\
\hline
\end{tabular}


Table 3. Regression equations, adjusted R-squared $\left(r^{2}\right), p$-values and F-values with degrees of freedom for each species between lake-specific due to low sample size. Regressions for PC2 are found as supplementary material in Table S3.

\begin{tabular}{|c|c|c|c|c|c|c|}
\hline Model & Whitefish & Vendace & Perch & Pike & Roach & Ruffe \\
\hline $\begin{array}{l}\text { THg (length) } \\
\sim \text { PC1 }\end{array}$ & $\begin{array}{l}y=-0.004 x+0.276 ; r^{2}=-0.06 \\
p=0.738 ; F_{1,14}=0.12\end{array}$ & $\begin{array}{l}y=0.067 x+0.217 ; r^{2}=0.16 \\
p=0.135 ; F_{1,8}=2.76\end{array}$ & $\begin{array}{l}{ }^{*} y=0.126 x+0.304 ; r^{2}=0.50 \\
p=0.006 ; F_{1,10}=12.01\end{array}$ & $\begin{array}{l}{ }^{*} y=0.108 x+1.179 ; r^{2}=0.29 \\
p=0.026 ; F_{1,12}=6,47\end{array}$ & $\begin{array}{l}y=0.093 x+0.183 ; r^{2}=0.57 \\
p=0.050 ; F_{1,4}=7.68\end{array}$ & $\begin{array}{l}\mathrm{y}=0.006 x+0.352 ; r^{2}=-0.08 \\
\mathrm{p}=0.831 ; \mathrm{F}_{1,12}=0.05\end{array}$ \\
\hline $\begin{array}{l}\text { THg (age) } \\
\sim \text { PC1 }\end{array}$ & $\begin{array}{l}y=0.000 x+0.296 ; r^{2}=-0.07 \\
p=0.972 ; F_{1,14}=0.00\end{array}$ & $\begin{array}{l}{ }^{*} y=0.078 x+0.208 ; r^{2}=0.50 \\
p=0.014 ; F_{1,8}=9.87\end{array}$ & $\begin{array}{l}{ }^{*} y=0.102 x+0.332 ; r^{2}=0.51 \\
p=0.005 ; F_{1,10}=12.53\end{array}$ & $\begin{array}{l}{ }^{*} y=0.104 x+1.159 ; r^{2}=0.55 \\
p=0.002 ; F_{1,12}=16.55\end{array}$ & $\begin{array}{l}{ }^{*} y=0.083 x+0.182 ; r^{2}=0.61 \\
p=0.024 ; F_{1,5}=10.25\end{array}$ & $\begin{array}{l}y=0.007 x+0.317 ; r^{2}=-0.07 \\
p=0.703 ; F_{1,12}=0.15\end{array}$ \\
\hline $\begin{array}{l}\text { Slope (length) } \\
\sim \text { PC1 }\end{array}$ & $\begin{array}{l}* y=0.002 x+0.007 ; r^{2}=0.34 \\
p=0.046 ; F_{1,8}=5.60\end{array}$ & $\begin{array}{l}y=0.017 x+0.011 ; r^{2}=0.28 \\
p=0.067 ; F_{1,8}=4.50\end{array}$ & $\begin{array}{l}* y=0.006 x^{2}-0.008 x+0.02 \\
r^{2}=0.73 ; p=0.002 ; F_{2,8}=14.3\end{array}$ & $\begin{array}{l}y=0.005 x+0.037 ; r^{2}=0.22 \\
p=0.052 ; F_{1,12}=4.65\end{array}$ & - & $\begin{array}{l}* y=0.005 x^{2}-0.006 x+0.02 ; \\
r^{2}=0.50 ; p=0.018 ; F_{2,9}=6.55\end{array}$ \\
\hline $\begin{array}{l}\text { Slope (age) } \\
\text { PC1 }\end{array}$ & $\begin{array}{l}{ }^{*} y=0.006 x+0.027 ; r^{2}=0.72 \\
p=0.002 ; F_{1,7}=21.74\end{array}$ & $\begin{array}{l}y=0.024 x+0.029 ; r^{2}=0.41 \\
p=0.053 ; F_{1,6}=5.78\end{array}$ & $\begin{array}{l}* y=0.012 x^{2}-0.012 x+0.05 \\
r^{2}=0.64 ; p=0.004 ; F_{2,9}=10.7\end{array}$ & $\begin{array}{l}{ }^{*} y=0.025 x+0.185 ; r^{2}=0.40 \\
p=0.009 ; F_{1,12}=9.58\end{array}$ & - & $\begin{array}{l}{ }^{*} y=0.004 x^{2}-0.009 x+0.033 \\
r^{2}=0.50 ; p=0.018 ; F_{2,9}=6.49\end{array}$ \\
\hline $\begin{array}{l}\text { THg (length) } \\
\sim \text { PC3 }\end{array}$ & $\begin{array}{l}y=0.036 x+0.274 ; r^{2}=0.17 \\
p=0.064 ; F_{1,14}=4.03\end{array}$ & $\begin{array}{l}y=-0.032 x+0.354 ; r^{2}=-0.01 \\
p=0.356 ; F_{1,8}=0.96\end{array}$ & $\begin{array}{l}y=0.094 x+0.508 ; r^{2}=0.19 \\
p=0.089 ; F_{1,10}=3.56\end{array}$ & $\begin{array}{l}y=0.170 x+1.145 ; r^{2}=0.17 \\
p=0.080 ; F_{1,12}=3.66\end{array}$ & $\begin{array}{l}y=0.030 x+0.433 ; r^{2}=0.05 \\
p=0.321 ; F_{1,4}=1.28\end{array}$ & $\begin{array}{l}y=0.053 x+0.362 ; r^{2}=0.12 \\
p=0.120 ; F_{1,12}=2.80\end{array}$ \\
\hline $\begin{array}{l}\text { THg (age) } \\
\sim \text { PC3 }\end{array}$ & $\begin{array}{l}y=0.035 x+0.293 ; r^{2}=0.14 \\
p=0.083 ; F_{1,14}=3.48\end{array}$ & $\begin{array}{l}y=0.049 x+0.376 ; r^{2}=0.32 \\
p=0.051 ; F_{1,8}=5.26\end{array}$ & $\begin{array}{l}y=0.067 x+0.496 ; r^{2}=0.13 \\
p=0.134 ; F_{1,10}=2.66\end{array}$ & $\begin{array}{l}y=0.062 x+1.145: r^{2}=-0.02 \\
p=0.420 ; F_{1,12}=0.70\end{array}$ & $\begin{array}{l}y=0.030 x+0.399 ; r^{2}=0.17 \\
p=0.194 ; F_{1,5}=2.25\end{array}$ & $\begin{array}{l}y=0.029 x+0.327 ; r^{2}=0.05 \\
p=0.221 ; F_{1,12}=1.66\end{array}$ \\
\hline $\begin{array}{l}\text { Slope (length) } \\
\sim \text { PC3 }\end{array}$ & $\begin{array}{l}y=0.000 x+0.005 ; r^{2}=-0.12 \\
p=0.855 ; F_{1,8}=0.037\end{array}$ & $\begin{array}{l}{ }^{*} y=0.016 x+0.047 ; r^{2}=0.50 \\
p=0.013 ; F_{1,8}=10.0\end{array}$ & $\begin{array}{l}{ }^{*} y=0.011 x+0.035 ; r^{2}=0.55 \\
p=0.005 ; F_{1,10}=13.28\end{array}$ & $\begin{array}{l}y=0.009 x+0.036 ; r^{2}=0.22 \\
p=0.054 ; F_{1,12}=4.56\end{array}$ & - & $\begin{array}{l}y=0.004 x+0.042 ; r^{2}=-0.02 \\
p=0.407 ; F_{1,10}=0.75\end{array}$ \\
\hline $\begin{array}{l}\text { Slope (age) } \\
\sim \text { PC3 }\end{array}$ & $\begin{array}{l}y=0.003 x+0.026 ; r^{2}=-0.06 \\
p=0.480 ; F_{1,7}=0.56\end{array}$ & $\begin{array}{l}y=0.016 x+0.079 ; r^{2}=0.32 \\
p=0.085 ; F_{1,6}=4.24\end{array}$ & $\begin{array}{l}y=0.019 x+0.098 ; r^{2}=0.23 \\
p=0.066 ; F_{1,10}=4.27\end{array}$ & $\begin{array}{l}* y=0.038 x+0.177 ; r^{2}=0.23 \\
p=0.046 ; F_{1,12}=4.95\end{array}$ & - & $\begin{array}{l}y=0.000 x+0.046 ; r^{2}=-0.10 \\
p=0.905 ; F_{1,10}=0.02\end{array}$ \\
\hline
\end{tabular}


FIGURE CAPTIONS

Fig. 1. The location of Tornio-Muoniojoki watercourse (mainstem forms a border between Finland and Sweden) and tributary lakes 1-18 (a) in northern Fennoscandia (b). Lakes are numbered according their PC1 scores. Asterisks indicate locations of six weather stations and their open-water season (June-September $1981-2010)$ air temperature $\left({ }^{\circ} \mathrm{C}\right)$ and precipitation $(\mathrm{mm})$. Arrows are flowing directions of rivers towards south and watercourse finally discharges to the northernmost part of Baltic Sea. Solid lines indicate distribution limit of coniferous trees, where Norway spruce border indicate the start of forestry practices. Mountain birch distribution covers the northernmost lake catchments.

Fig. 2. Results of principal component analysis (PCA) representing the first three axes explaining most of the variation (total $84 \%$ ) with a total of 14 environmental variables (Table 1 ) presented in three bi-plots $(a, b, c)$. The first axis (PC1) describes climate-productivity, the second axis (PC2) lake morphometry, and the third axis (PC3) catchment magnitude. The arrow lengths indicate the importance of an environmental variable. For lake scores, see Table 1 and for variable loadings, see Table S2.

Fig. 3. The relationship between climate-productivity factor (PC1, for clarity opposite lake score values are used) to species-specific length-adjusted THg concentrations (the topmost row) and ageadjusted THg concentrations (the second row), as well as $\mathrm{THg}$ bioaccumulation rate relative to length (the third row) and age (the fourth row). Please note that THg concentrations are indicated as dry weight. The regression lines and $95 \%$ confidence intervals are added only to statistically significant $(p<0.05)$ cases. For regression equations, see Table 3. 


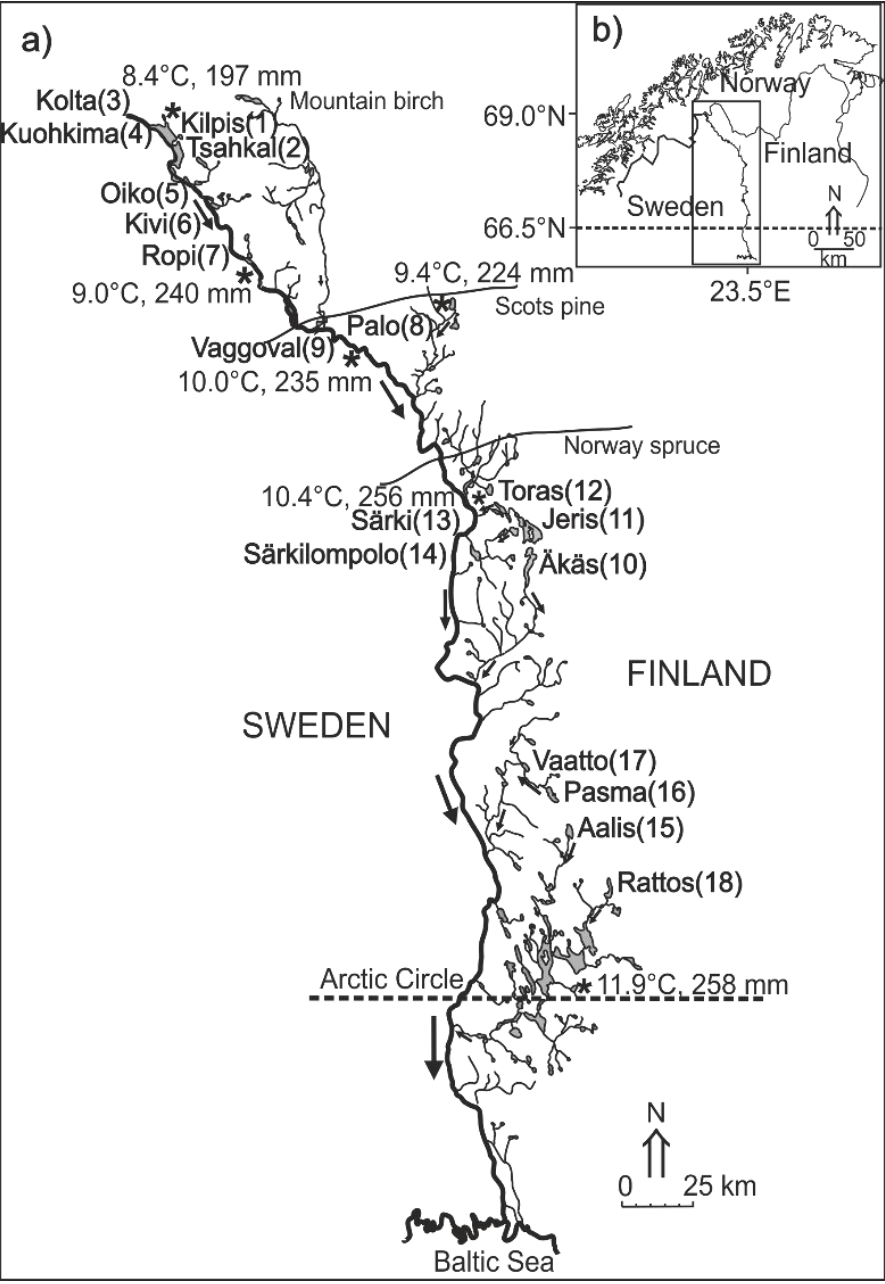

$806 \quad$ Fig. 1

807 

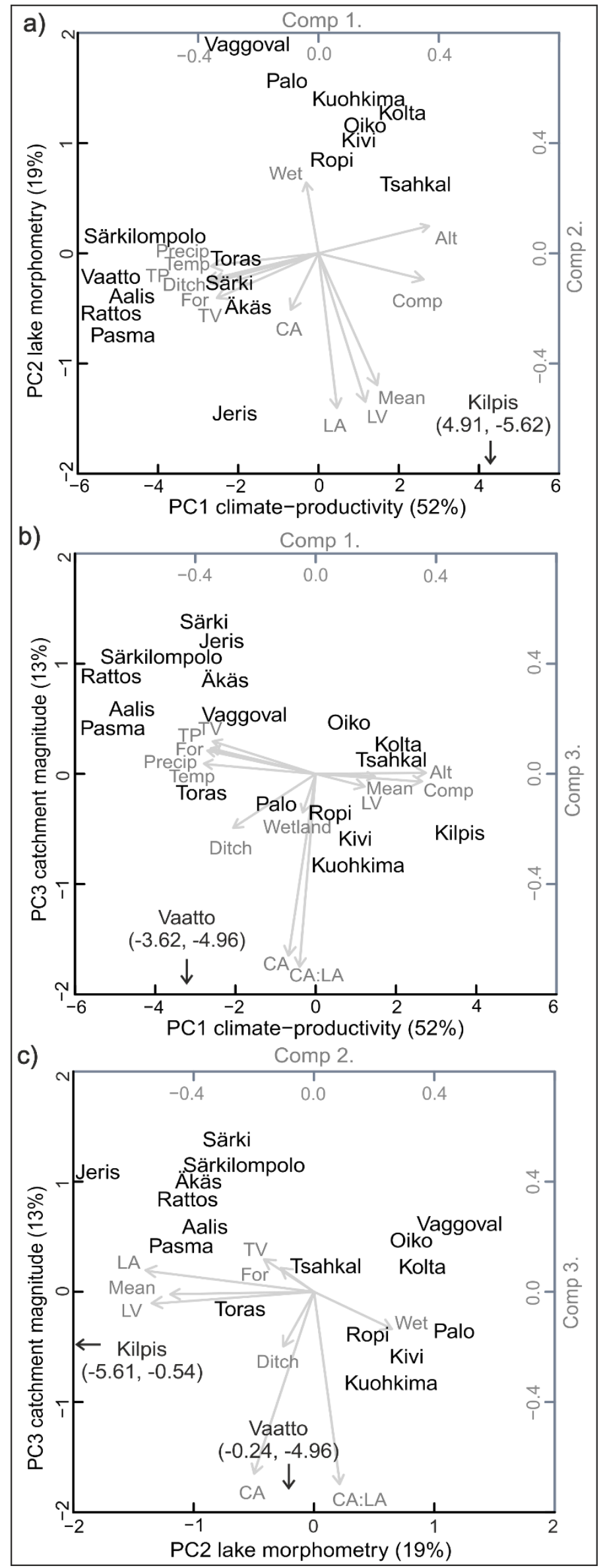
809

Fig. 2.

810

811
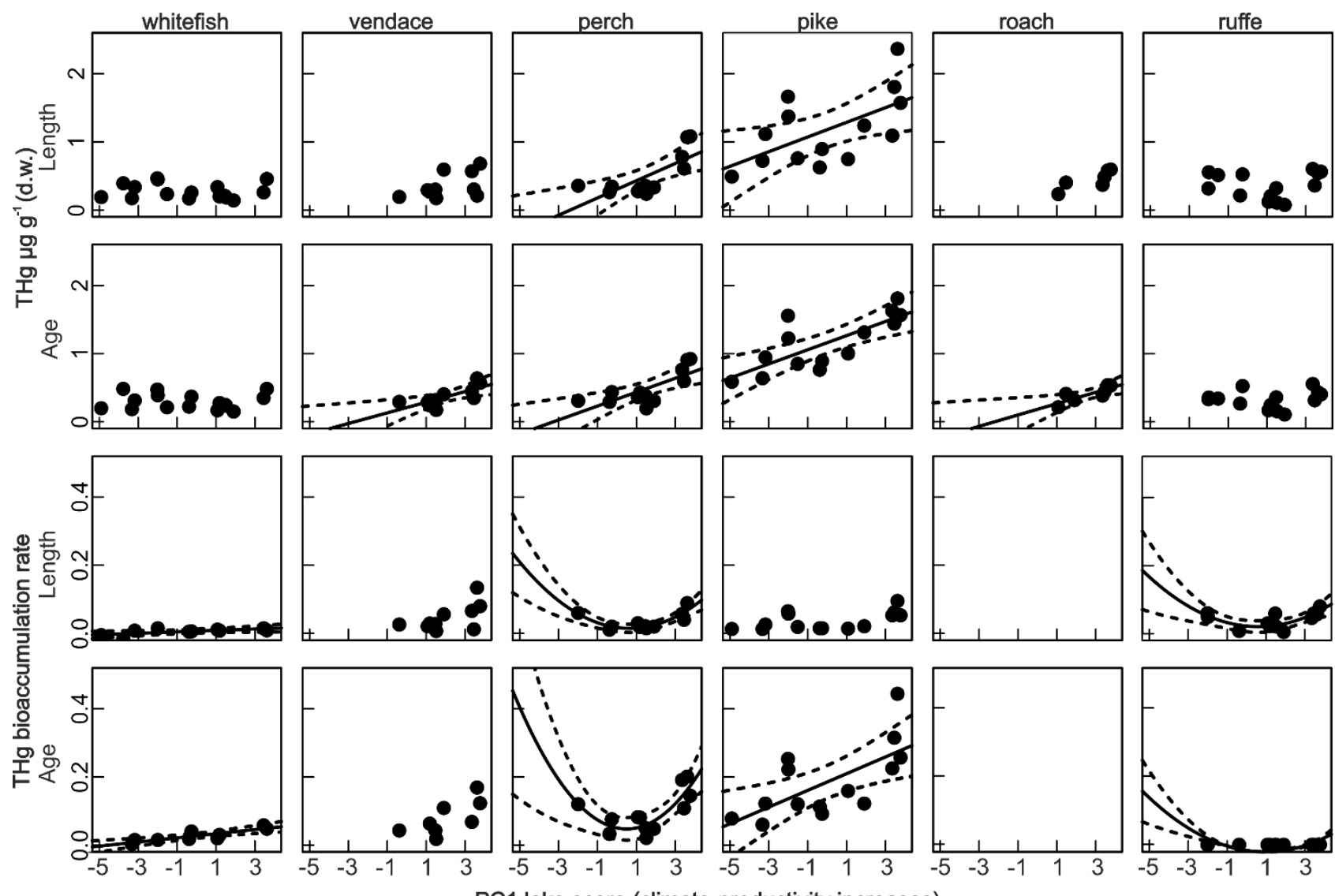

PC1 lake score (climate-productivity increases)

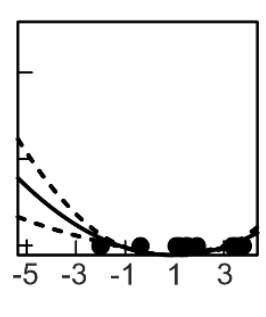

812

813

Fig. 3. 


\section{SUPPLEMENTARY INFORMATION}

Table S1. Study lakes and environmental variables that were excluded from PCA-analysis due to collinearity. Latitude (Lat), longitude (Long), total nitrogen (TN) maximum depth (Max depth), littoral portion of the lakes (Litt), the amount of fish species (Species), number of households (HH), urban (Urban), agriculture, sparse vegetation and water percentages in the lake catchment. Please note that lakes (column No) are ordered by PC1 scores. 


\begin{tabular}{|c|c|c|c|c|c|c|c|c|c|c|c|c|}
\hline No & Lake & $\begin{array}{l}\text { Lat } \\
\left({ }^{\circ} \mathrm{N}\right)\end{array}$ & $\begin{array}{l}\text { Long } \\
\left({ }^{\circ} \mathrm{E}\right)\end{array}$ & $\begin{array}{r}\mathrm{TN} \\
(\mu \mathrm{g} \mathrm{L}-1)\end{array}$ & $\begin{array}{r}\text { Max depth } \\
(\mathrm{m})\end{array}$ & $\begin{array}{l}\text { Litt } \\
\text { (\%) }\end{array}$ & $\begin{array}{r}\text { Species } \\
n\end{array}$ & $\begin{array}{r}\mathrm{HH} \\
\left(\mathrm{km}^{2}\right)\end{array}$ & $\begin{array}{r}\text { Urban } \\
(\%)\end{array}$ & $\begin{array}{r}\text { Agriculture } \\
(\%)\end{array}$ & $\begin{array}{r}\text { Sparse veg. } \\
(\%)\end{array}$ & $\begin{array}{r}\text { Water } \\
(\%)\end{array}$ \\
\hline 1 & Kilpis & 69.03 & 20.49 & 120 & 57 & 29 & 8 & 7 & 0.71 & 0 & 70.64 & 15.65 \\
\hline 2 & Tsahkal & 69.01 & 20.55 & 140 & 30 & 60 & 4 & 0 & 0 & 0 & 89.43 & 5.28 \\
\hline 3 & Kolta & 69.03 & 20.30 & 97 & 3 & 100 & 6 & 2 & 0 & 0 & 79.10 & 10.00 \\
\hline 4 & Kuohkima & 69.03 & 20.33 & 200 & 10 & 99 & 6 & 7 & 0 & 0 & 78.30 & 12.00 \\
\hline 5 & Oiko & 68.50 & 21.13 & 215 & 10 & 84 & 9 & 3 & 0.19 & 0 & 61.99 & 7.76 \\
\hline 6 & Kivi & 68.49 & 21.15 & 201 & 10 & 84 & 9 & 1 & 0 & 0 & 74.22 & 5.19 \\
\hline 7 & Ropi & 68.41 & 21.35 & 273 & 20 & 54 & 11 & 11 & 0 & 0 & 65.43 & 3.49 \\
\hline 8 & Palo & 68.34 & 23.21 & 470 & 2 & 100 & 8 & 11 & 0.42 & 0.10 & 31.39 & 4.33 \\
\hline 9 & Vaggoval & 68.30 & 22.14 & 590 & 2.5 & 100 & 7 & 15 & 0.19 & 0 & 0.29 & 24.48 \\
\hline 10 & Akas & 67.49 & 24.07 & 350 & 12 & 77 & 8 & 7 & 0.79 & 0.19 & 14.35 & 15.85 \\
\hline 11 & Jeris & 67.55 & 24.06 & 550 & 12 & 59 & 9 & 15 & 1.49 & 0.39 & 9.45 & 24.47 \\
\hline 12 & Toras & 67.58 & 23.52 & 600 & 8.5 & 51 & 10 & 7 & 0.90 & 0.20 & 9.20 & 17.5 \\
\hline 13 & Särki & 67.54 & 23.58 & 520 & 14 & 14 & 6 & 18 & 2.18 & 0.19 & 9.25 & 25.47 \\
\hline 14 & Särkilompolo & 67.54 & 23.54 & 420 & 8.3 & 30 & 8 & 45 & 1.39 & 0.09 & 8.35 & 14.62 \\
\hline 15 & Aalis & 67.00 & 24.32 & 830 & 6 & 19 & 9 & 7 & 0.79 & 0.29 & 16.10 & 7.96 \\
\hline 16 & Pasma & 67.07 & 24.22 & 1100 & 4.1 & 99 & 8 & 12 & 0.99 & 0.99 & 16.08 & 6.29 \\
\hline 17 & Vaatto & 67.12 & 24.09 & 470 & 4.5 & 33 & 8 & 49 & 0.59 & 0.89 & 13.48 & 2.69 \\
\hline 18 & Rattos & 66.50 & 24.52 & 520 & 6.8 & 32 & 8 & 21 & 0.99 & 0.69 & 13.61 & 7.45 \\
\hline
\end{tabular}




\begin{tabular}{rrrrrrrrrrrrrrrrrr}
\hline & Alt & Precip & Temp & TP & Comp & Mean & LV & LA & CA & For & Wet & Ditch & TV & CA:LA \\
\hline Comp.1 & 0.36 & -0.35 & -0.36 & -0.34 & 0.35 & 0.19 & 0.15 & 0.06 & -0.09 & -0.35 & -0.04 & -0.27 & -0.33 & -0.05 \\
Comp.2 & 0.10 & -0.04 & -0.10 & -0.09 & -0.09 & -0.47 & -0.53 & -0.55 & -0.20 & -0.11 & 0.25 & -0.10 & -0.16 & 0.09 \\
Comp.3 & 0.00 & 0.08 & 0.04 & 0.09 & -0.03 & -0.01 & -0.04 & 0.08 & -0.65 & 0.08 & -0.13 & -0.19 & 0.11 & -0.69 \\
\hline
\end{tabular}

Table S2. Loadings of the 14 selected environmental variables in three first components of PCA analysis including Alt (altitude), Precip (precipitation), Temp (temperature), TP (total phosphorus), Comp (compensation depth), Mean (mean depth), LV (lake volume), LA (lake area), CA (catchment area), For (forested area of the catchment), Wet (wetland area of the catchment), Ditch (ditch kilometers per catchment area), TV (tree volume in the catchment), and CA:LA (catchment-lake area ratio). The farther the value is from zero, the more significance it has in the component. See Table 1 for units.

829 


\begin{tabular}{|c|c|c|c|c|c|c|}
\hline Model & Whitefish & Vendace & Perch & Pike & Roach & Ruffe \\
\hline $\begin{array}{l}\text { THg } \\
\text { (length) } \sim \text { PC2 }\end{array}$ & $\begin{array}{l}y=-0.016 x+0.277 ; r^{2}=-0.00 \\
p=0.340 ; F_{1,14}=0.98\end{array}$ & $\begin{array}{l}y=0.042 x+0.346 ; r^{2}=-0.09 \\
p=0.628 ; F_{1,8}=0.25\end{array}$ & $\begin{array}{l}y=0.091 x+0.503 ; r^{2}=-0.00 ; \\
p=0.359 ; F_{1,10}=0.92\end{array}$ & $\begin{array}{l}y=-0.036 x+1.172 ; r^{2}=-0.07 \\
p=0.663 ; F_{1,12}=0.20\end{array}$ & $\begin{array}{l}y=-0.138 x+0.503 ; r^{2}=-0.21 \\
p=0.740 ; F_{1,4}=0.13\end{array}$ & $\begin{array}{l}y=-0.042 x+0.351 ; r^{2}=0.03 \\
p=0.457 ; F_{1,12}=0.59\end{array}$ \\
\hline $\begin{array}{l}\text { THg } \\
\text { (age) PC2 }\end{array}$ & $\begin{array}{l}y=-0.018 x+0.295 ; r^{2}=0.01 \\
p=0.298 ; F_{1,14}=1.17\end{array}$ & $\begin{array}{l}y=0.001 x+0.371 ; r^{2}=-0.13 \\
p=0.983 ; F_{1,8}=0.00\end{array}$ & $\begin{array}{l}y=0.082 x+0.492 ; r^{2}=0.02 \\
p=0.299 ; F_{1,10}=1.20\end{array}$ & $\begin{array}{l}y=-0.016 x+1.155 ; r^{2}=-0.08 \\
p=0.799 ; F_{1,12}=0.07\end{array}$ & $\begin{array}{l}y=0.035 x+0.391 ; r^{2}=-0.19 \\
p=0.877 ; F_{1,5}=0.03\end{array}$ & $\begin{array}{l}y=-0.032 x+0.319 ; r^{2}=-0.02 ; \\
p=0.411 ; F_{1,12}=0.73\end{array}$ \\
\hline $\begin{array}{l}\text { Slope } \\
\text { (length) PC2 }\end{array}$ & $\begin{array}{l}y=-0.001 x+0.006 ; r^{2}=-0.06 \\
p=0.487 ; F_{1,8}=0.53\end{array}$ & $\begin{array}{l}y=0.001 x+0.046 ; r^{2}=-0.12 ; \\
p=0.943 ; F_{1,8}=0.01\end{array}$ & $\begin{array}{l}y=0.003 x+0.035 ; r^{2}=-0.10 ; \\
p=0.721 ; F_{1,9}=0.14\end{array}$ & $\begin{array}{l}y=0.000 x+0.037 ; r^{2}=-0.08 \\
p=0.913 ; F_{1,12}=0.01\end{array}$ & - & $\begin{array}{l}y=0.003 x+0.041 ; r^{2}=-0.09 \\
p=0.765 ; F_{1,10}=0.09\end{array}$ \\
\hline $\begin{array}{l}\text { Slope } \\
\text { (age) PC2 }\end{array}$ & $\begin{array}{l}y=0.007 x+0.03 ; r^{2}=0.08 \\
p=0.234 ; F_{1,7}=1.70\end{array}$ & $\begin{array}{l}y=0.009 x+0.078 ; r^{2}=-0.14 \\
p=0.721 ; F_{1,6}=0.14\end{array}$ & $\begin{array}{l}y=0.015 x+0.097 ; r^{2}=-0.03 ; \\
p=0.441 ; F_{1,10}=0.64\end{array}$ & $\begin{array}{l}y=0.001 x+0.185 ; r^{2}=-0.08 \\
p=0.946 ; F_{1,12}=0.01\end{array}$ & - & $\begin{array}{l}y=-0.003 x+0.046 ; r^{2}=-0.09 ; \\
p=0.719 ; F_{1,10}=0.14\end{array}$ \\
\hline
\end{tabular}


Table S4. Lake-specific linear regression equations, adjusted R-squared $\left(r^{2}\right)$, p-values and F-values with degrees of freedom between THg concentration ( $\mu \mathrm{g} \mathrm{g}^{-1} \mathrm{dry}$ weight) and fish total length $(\mathrm{cm})$ for each species. Statistically significant $(p<0.05)$ equations are bolded. Please note that lakes (column No) are ordered by PC1 scores. 


\begin{tabular}{|c|c|c|c|c|c|c|}
\hline Lake & Whitefish & Vendace & Perch & Pike & Roach & Ruffe \\
\hline 1. Kilpis & $\begin{array}{l}y=-0.005 x+0.306 ; r^{2}=0.26 \\
p<0.01 ; F_{1,28}=11.08\end{array}$ & - & - & $\begin{array}{l}y=0.013 x-0.166 ; r^{2}=0.70 \\
p<0.001 ; F_{1,28}=69.24\end{array}$ & - & - \\
\hline 2. Tsahkal & $\begin{array}{l}y=-0.016 x+0.766 ; r^{2}=0.23 \\
p<0.01 ; F_{1,28}=9.57\end{array}$ & - & - & - & - & - \\
\hline 3. Kolta & $\begin{array}{l}y=0.001 x+0.162 ; r^{2}=0.04 \\
p=0.138 ; F_{1,28}=2.34\end{array}$ & - & - & $\begin{array}{l}y=0.013 x+0.066 ; r^{2}=0.81 ; \\
p<0.001 ; F_{1,14}=66.50\end{array}$ & - & - \\
\hline 4. Kuohkima & $\begin{array}{l}y=0.008 x+0.149 ; r^{2}=0.21 ; \\
p<0.01 ; F_{1,28}=8.64\end{array}$ & - & - & $\begin{array}{l}y=0.026 x-0.197 ; r^{2}=0.56 \\
p<0.001 ; F_{1,16}=23.07\end{array}$ & - & - \\
\hline 5. Oiko & $\begin{array}{l}y=0.002 x+0.423 ; r^{2}=0.05 \\
p=0.239 ; F_{1,28}=1.45\end{array}$ & - & - & $\begin{array}{l}y=0.065 x-1.616 r^{2}=0.70 \\
p<0.001 ; F_{1,25}=62.77\end{array}$ & - & $\begin{array}{l}y=0.061 x-0.259 ; r^{2}=0.61 ; \\
p<0.001 ; F_{1,28}=45.84\end{array}$ \\
\hline 6. Kivi & $\begin{array}{l}y=0.015 x+0.098 ; r^{2}=0.46 \\
p<0.001 ; F_{1,28}=25.21\end{array}$ & - & $\begin{array}{l}y=0.060 x-0.626 ; r^{2}=0.58 \\
p<0.001 ; F_{1,28}=41.23\end{array}$ & $\begin{array}{l}y=0.058 x-1.553 ; r^{2}=0.61 ; \\
p<0.001 ; F_{1,16}=26.99\end{array}$ & - & $\begin{array}{l}y=0.049 x+0.085 ; r^{2}=0.19 \\
p<0.05 ; F_{1,28}=7.73\end{array}$ \\
\hline 7. Ropi & $\begin{array}{l}y=0.005 x+0.107 ; r^{2}=0.01 \\
p=0.249 ; F_{1,28}=1.39\end{array}$ & - & - & $\begin{array}{l}y=0.019 x-0.200 ; r^{2}=0.52 \\
p<0.001 ; F_{1,20}=23.83\end{array}$ & - & $\begin{array}{l}y=-0.031 x+0.810 ; r^{2}=0.06 \\
p=0.156 ; F_{1,19}=2.18\end{array}$ \\
\hline 8. Palo & $\begin{array}{l}y=0.005 x+0.053 ; r^{2}=0.53 \\
p<0.001 ; F_{1,28}=33.21\end{array}$ & $\begin{array}{l}y=0.026 x-0.162 ; r^{2}=0.72 ; \\
p<0.001 ; F_{1,28}=74.53\end{array}$ & $\begin{array}{l}y=0.011 x+0.082 ; r^{2}=0.63 ; \\
p<0.001 ; F_{1,28}=51.13\end{array}$ & $\begin{array}{l}y=0.015 x-0.132 ; r^{2}=0.82 \\
p<0.001 ; F_{1,13}=66.37\end{array}$ & - & $\begin{array}{l}y=0.008 x+0.136 ; r^{2}=0.29 \\
p<0.005 ; F_{1,28}=13.0\end{array}$ \\
\hline 9. Vaggoval & $\begin{array}{l}y=0.006 x+0.116 ; r^{2}=0.51 ; \\
p<0.001 ; F_{1,28}=31.10\end{array}$ & - & $\begin{array}{l}y=0.020 x+0.016 ; r^{2}=0.64 ; \\
p<0.001 ; F_{1,28}=52.28\end{array}$ & $\begin{array}{l}y=0.015 x+0.138 ; r^{2}=0.67 \\
p<0.001 ; F_{1,25}=52.73\end{array}$ & - & $\begin{array}{l}y=0.010 x+0.430 ; r^{2}=-0.04 ; \\
p=0.789 ; F_{1,26}=0.07\end{array}$ \\
\hline 10. Äkäs & $\begin{array}{l}y=0.011 x-0.079 ; r^{2}=0.67 \\
p<0.001 ; F_{1,28}=59.37\end{array}$ & $\begin{array}{l}y=0.021 x+0.005 ; r^{2}=0.20 \\
p<0.01 ; F_{1,28}=8.00\end{array}$ & $\begin{array}{l}y=0.030 x-0.216 ; r^{2}=0.85 \\
p<0.001 ; F_{1,27}=164.49\end{array}$ & $\begin{array}{l}y=0.014 x+0.040 ; r^{2}=0.81 ; \\
p<0.01 ; F_{1,4}=22.50\end{array}$ & $\begin{array}{l}y=-0.007 x+0.321 ; r^{2}=0.05 \\
p=0.132 ; F_{1,28}=2.41\end{array}$ & $\begin{array}{l}y=0.030 x-0.167 ; r^{2}=0.72 \\
p<0.001 ; F_{1,28}=76.90\end{array}$ \\
\hline 11. Jeris & $\begin{array}{l}y=0.008 x+0.012 ; r^{2}=0.42 \\
p<0.001 ; F_{1,28}=21.83\end{array}$ & $\begin{array}{l}y=0.029 x-0.128 ; r^{2}=0.66 \\
p<0.001 ; F_{1,28}=56.10\end{array}$ & $\begin{array}{l}y=0.020 x-0.002 ; r^{2}=0.50 \\
p<0.001 ; F_{1,25}=26.83\end{array}$ & - & - & $\begin{array}{l}y=0.022 x-0.006 ; r^{2}=0.68 \\
p<0.001 ; F_{1,28}=61.10\end{array}$ \\
\hline 12. Toras & $\begin{array}{l}y=0.001 x+0.217 ; r^{2}=-0.02 \\
p=0.575 ; F_{1,28}=0.32\end{array}$ & $\begin{array}{l}y=0.028 x-0.082 ; r^{2}=0.61 \\
p<0.001 ; F_{1,28}=45.83\end{array}$ & $\begin{array}{l}y=0.021 \times 0.008 ; r^{2}=0.64 \\
p<0.001 ; F_{1,28}=53.21\end{array}$ & - & $\begin{array}{l}y=0.010 x+0.261 ; r^{2}=0.07 \\
p=0.079 ; F_{1,28}=3.32\end{array}$ & $\begin{array}{l}y=0.059 x-0.245 ; r^{2}=0.45 \\
p<0.001 ; F_{1,28}=24.76\end{array}$ \\
\hline 13. Särki & $\begin{array}{l}y=-0.003 x+0.268 ; r^{2}=0.02 \\
p=0.201 ; F_{1,28}=1.71\end{array}$ & $\begin{array}{l}y=0.007 x+0.078 ; r^{2}=0.18 \\
p<0.05 ; F_{1,28}=7.51\end{array}$ & $\begin{array}{l}y=0.015 x-0.008 ; r^{2}=0.47 ; \\
p<0.001 ; F_{1,28}=26.97\end{array}$ & - & - & $\begin{array}{l}y=0.021 x-0.094 ; r^{2}=0.78 \\
p<0.001 ; F_{1,28}=106.35\end{array}$ \\
\hline 14. Särkilomp & $\begin{array}{l}y=-0.001 x+0.173 ; r^{2}=-0.03 \\
p=0.586 ; F_{1,28}=0.30\end{array}$ & $\begin{array}{l}y=0.056 x-0.170 ; r^{2}=0.56 \\
p<0.001 ; F_{1,28}=37.37\end{array}$ & $\begin{array}{l}y=0.020 x+0.005 ; r^{2}=0.67 \\
p<0.001 ; F_{1,28}=58.62\end{array}$ & $\begin{array}{l}y=0.021 x+0.180 ; r^{2}=0.56 \\
p<0.001 ; F_{1,15}=21.56\end{array}$ & - & $\begin{array}{l}y=0.005 x+0.027 ; r^{2}=0.78 \\
p<0.001 ; F_{1,28}=103.86\end{array}$ \\
\hline 15. Aalis & - & $\begin{array}{l}y=0.066 x-0.330 ; r^{2}=0.16 \\
p<0.05 ; F_{1,28}=6.460\end{array}$ & $\begin{array}{l}y=0.057 x-0.152 ; r^{2}=0.73 \\
p<0.001 ; F_{1,28}=79.53\end{array}$ & $\begin{array}{l}y=0.053 x-1.582 ; r^{2}=0.69 \\
p<0.001 ; F_{1,28}=66.75\end{array}$ & $\begin{array}{l}y=0.008 x+0.279 . r^{2}=0.02 \\
p=0.207 ; F_{1,28}=1.67\end{array}$ & $\begin{array}{l}y=0.046 x+0.161 ; r^{2}=0.17 \\
p<0.05 ; F_{1,28}=6.88\end{array}$ \\
\hline 16. Pasma & $\begin{array}{l}y=0.015 x-0.092 ; r^{2}=0.57 \\
p<0.001 ; F_{1,28}=39.53\end{array}$ & $\begin{array}{l}y=0.012 x+0.138 ; r^{2}=0.18 \\
p<0.05 ; F_{1,28}=7.35\end{array}$ & $\begin{array}{l}y=0.040 x-0.046 . r^{2}=0.83 \\
p<0.001 ; F_{1,27}=141.92\end{array}$ & $\begin{array}{l}y=0.062 x-1.322 ; r^{2}=0.63 \\
p<0.001 ; F_{1,22}=40.41\end{array}$ & $\begin{array}{l}y=0.031 x+0.047 ; r^{2}=0.64 ; \\
p=0.000 ; F_{1,28}=51.64\end{array}$ & $\begin{array}{l}y=0.059 x-0.206 ; r^{2}=0.66 \\
p<0.001 ; F_{1,28}=56.30\end{array}$ \\
\hline 17. Vaatto & $\begin{array}{l}y=0.009 x+0.245 ; r^{2}=0.26 \\
p<0.05 ; F_{1,12}=5.44\end{array}$ & $\begin{array}{l}y=0.134 x-1.615 ; r^{2}=0.80 \\
p<0.001 ; F_{1,11}=49.43\end{array}$ & $\begin{array}{l}y=0.089 x-0.387 ; r^{2}=0.55 \\
p<0.001 ; F_{1,28}=36.51\end{array}$ & $\begin{array}{l}y=0.095 x-2.429 ; r^{2}=0.77 \\
p<0.001 ; F_{1,26}=93.58\end{array}$ & $\begin{array}{l}y=0.019 x+0.310 ; r^{2}=0.17 \\
p<0.05 ; F_{1,28}=6.82\end{array}$ & $\begin{array}{l}y=0.057 x-0.004 ; r^{2}=0.37 \\
p<0.001 ; F_{1,28}=17.77\end{array}$ \\
\hline 18. Rattos & - & $\begin{array}{l}y=0.080 x-0.411 ; r^{2}=0.46 ; \\
p<0.001 ; F_{1,28}=25.32\end{array}$ & $\begin{array}{l}y=0.038 x+0.389 ; r^{2}=0.09 ; \\
p=0.062 ; F_{1,28}=3.78\end{array}$ & $\begin{array}{l}y=0.053 x-1.102 ; r^{2}=0.84 ; \\
p<0.001 ; F_{1,24}=132.83\end{array}$ & $\begin{array}{l}y=0.042 x+0.000 ; r^{2}=0.51 ; \\
p=0.000 ; F_{1,28}=30.88\end{array}$ & $\begin{array}{l}y=0.080 x-0.205 ; r^{2}=0.419 ; \\
p<0.001 ; F_{1,28}=21.82\end{array}$ \\
\hline
\end{tabular}




\begin{tabular}{|c|c|c|c|c|c|c|}
\hline Lake & Whitefish & Vendace & Perch & Pike & Roach & Ruffe \\
\hline 1. Kilpis & $\begin{array}{l}y=-0.006 x+0.207 ; r^{2}=0.01 \\
p=0.276 ; F_{1,28}=1.24\end{array}$ & - & - & $\begin{array}{l}y=0.078 \times 0+0.099 ; r^{2}=0.71 ; \\
p<0.001 ; F_{1,28}=74.19\end{array}$ & - & - \\
\hline 2. Tsahkal & $\begin{array}{l}y=-0.016 x+0.571 ; r^{2}=0.05 \\
p=0.115 ; F_{1,28}=2.65\end{array}$ & - & - & - & - & - \\
\hline 3. Kolta & $\begin{array}{l}y=0.003 x+0.170 ; r^{2}=0.13 \\
p<0.05 ; F_{1,28}=5.31\end{array}$ & - & - & $\begin{array}{l}y=0.060 x+0.263 ; r^{2}=0.87 \\
p<0.001 ; F_{1,14}=98.48\end{array}$ & - & - \\
\hline 4. Kuohkima & $\begin{array}{l}y=0.015 x+0.242 ; r^{2}=0.32 \\
p<0.001 ; F_{1,28}=14.52\end{array}$ & - & - & $\begin{array}{l}y=0.122 x+0.181 ; r^{2}=0.60 \\
p<0.001 ; F_{1,16}=26.78\end{array}$ & - & - \\
\hline 5. Oiko & $\begin{array}{l}y=0.007 x+0.437 ; r^{2}=0.020 \\
p=0.22 ; F_{1,28}=1.55\end{array}$ & - & - & $\begin{array}{l}y=0.253 x-0.024 ; r^{2}=0.84 \\
p<0.001 ; F_{1,25}=133.68\end{array}$ & - & $\begin{array}{l}y=0.076 x+0.056 ; r^{2}=0.71 ; \\
p<0.001 ; F_{1,28}=72.99\end{array}$ \\
\hline 6. Kivi & $\begin{array}{l}y=0.015 x+0.317 ; r^{2}=0.16 \\
p<0.05 ; F_{1,28}=6.62\end{array}$ & - & $\begin{array}{l}y=0.120 x-0.245 ; r^{2}=0.51 ; \\
p<0.001 ; F_{1,28}=31.27\end{array}$ & $\begin{array}{l}y=0.222 x-0.163 ; r^{2}=0.87 \\
p<0.001 ; F_{1,16}=118.50\end{array}$ & - & $\begin{array}{l}y=0.071 x+0.064 ; r^{2}=0.66 \\
p<0.001 ; F_{1,28}=58.20\end{array}$ \\
\hline 7. Ropi & $\begin{array}{l}y=0.016 x+0.153 ; r^{2}=0.10 \\
p=0.051 ; F_{1,28}=4.17\end{array}$ & - & - & $\begin{array}{l}y=0.120 x+0.100 ; r^{2}=0.50 \\
p<0.001 ; F_{1,20}=22.05\end{array}$ & - & $\begin{array}{l}y=0.036 x+0.240 ; r^{2}=0.06 \\
p=0.154 ; F_{1,19}=2.20\end{array}$ \\
\hline 8. Palo & $\begin{array}{l}y=0.018 x+0.137 ; r^{2}=0.60 ; \\
p<0.001 ; F_{1,28}=44.76\end{array}$ & $\begin{array}{l}y=0.043 x+0.154 ; r^{2}=0.60 \\
p=0.000 ; F_{1,28}=43.99\end{array}$ & $\begin{array}{l}y=0.033 x+0.139 ; r^{2}=0.59 ; \\
p<0.001 ; F_{1,28}=42.00\end{array}$ & $\begin{array}{l}y=0.113 x+0.057 ; r^{2}=0.73 \\
p<0.001 ; F_{1,13}=38.03\end{array}$ & - & $\begin{array}{l}y=0.027 x+0.155 ; r^{2}=0.37 \\
p<0.001 ; F_{1,28}=17.86\end{array}$ \\
\hline 9. Vaggoval & $\begin{array}{l}y=0.040 x+0.181 ; r^{2}=0.36 \\
p<0.001 ; F_{1,28}=17.17\end{array}$ & - & $\begin{array}{l}y=0.076 x+0.086 ; r^{2}=0.76 \\
p<0.001 ; F_{1,28}=90.31\end{array}$ & $\begin{array}{l}y=0.092 x+0.315 ; r^{2}=0.75 \\
p<0.001 ; F_{1,25}=79.70\end{array}$ & - & $\begin{array}{l}y=-0.007 x+0.543 ; r^{2}=-0.04 ; \\
p=0.925 ; F_{1,26}=0.01\end{array}$ \\
\hline 10. Akas & $\begin{array}{l}y=0.020 x+0.074 ; r^{2}=0.63 \\
p<0.001 ; F_{1,28}=50.58\end{array}$ & $\begin{array}{l}y=0.020 x+0.191 ; r^{2}=0.09 \\
p=0.061 ; F_{1,28}=3.83\end{array}$ & $\begin{array}{l}y=0.082 x-0.016 ; r^{2}=0.63 \\
p<0.001 ; F_{1,28}=48.40\end{array}$ & $\begin{array}{l}y=0.159 x+0.009 ; r^{2}=0.77 \\
p<0.05 ; F_{1,4}=17.73\end{array}$ & $\begin{array}{l}y=-0.006 x+0.245 ; r^{2}=0.02 \\
p=0.502 ; F_{1,28}=0.46\end{array}$ & $\begin{array}{l}y=0.033 x+0.033 ; r^{2}=0.81 \\
p<0.001 ; F_{1,28}=128.30\end{array}$ \\
\hline 11. Jeris & $\begin{array}{l}y=0.030 x+0.134 ; r^{2}=0.25 \\
p<0.01 ; F_{1,28}=10.45\end{array}$ & $\begin{array}{l}y=0.063 x+0.038 ; r^{2}=0.78 \\
p=0.000 ; F_{1,28}=104.69\end{array}$ & $\begin{array}{l}y=0.080 x+0.054 ; r^{2}=0.36 \\
p<0.001 ; F_{1,28}=15.42\end{array}$ & - & - & $\begin{array}{l}y=0.032 x+0.113 ; r^{2}=0.61 ; \\
p<0.001 ; F_{1,28}=45.44\end{array}$ \\
\hline 12. Toras & $\begin{array}{l}y=-0.001 x+0.235 ; r^{2}=-0.04 ; \\
p=0.918 ; F_{1,28}=0.01\end{array}$ & $\begin{array}{l}y=0.043 x+0.180 ; r^{2}=0.59 \\
p=0.000 ; F_{1,28}=42.30\end{array}$ & $\begin{array}{l}y=0.050 x+0.150 ; r^{2}=0.39 \\
p<0.001 ; F_{1,28}=19.78\end{array}$ & - & $\begin{array}{l}y=0.018 x+0.297 ; r^{2}=0.15 \\
p=0.021 ; F_{1,28}=5.97\end{array}$ & $\begin{array}{l}y=0.056 x+0.128 ; r^{2}=0.43 \\
p<0.001 ; F_{1,28}=22.47\end{array}$ \\
\hline 13. Särki & $\begin{array}{l}y=-0.002 x+0.224 ; r^{2}=-0.02 ; \\
p=0.515 ; F_{1,28}=0.44\end{array}$ & $\begin{array}{l}y=0.018 x+0.115 ; r^{2}=0.39 \\
p=0.000 ; F_{1,28}=19.18\end{array}$ & $\begin{array}{l}y=0.021 x+0.099 ; r^{2}=0.59 \\
p<0.001 ; F_{1,28}=42.31\end{array}$ & - & - & $\begin{array}{l}y=0.022 x+0.064 ; r^{2}=0.88 \\
p<0.001 ; F_{1,28}=218.05\end{array}$ \\
\hline 14. Särkilom. & $\begin{array}{l}y=0.000 x+0.154 ; r^{2}=-0.04 \\
p=0.937 ; F_{1,28}=0.01\end{array}$ & $\begin{array}{l}y=0.109 x+0.054 ; r^{2}=0.44 \\
p=0.000 ; F_{1,28}=23.56\end{array}$ & $\begin{array}{l}y=0.048 x+0.085 ; r^{2}=0.67 \\
p<0.001 ; F_{1,28}=59.76\end{array}$ & $\begin{array}{l}y=0.122 x+0.549 ; r^{2}=0.49 \\
p<0.001 ; F_{1,15}=16.28\end{array}$ & - & $\begin{array}{l}y=0.013 x+0.053 ; r^{2}=0.85 \\
p<0.001 ; F_{1,28}=161.67\end{array}$ \\
\hline 15. Aalis & - & $\begin{array}{l}y=0.068 x+0.233 ; r^{2}=0.14 \\
p=0.025 ; F_{1,28}=5.57\end{array}$ & $\begin{array}{l}y=0.191 x-0.115 ; r^{2}=0.72 \\
p<0.001 ; F_{1,28}=77.19\end{array}$ & $\begin{array}{l}y=0.225 x+0.220 ; r^{2}=0.85 \\
p<0.001 ; F_{1,28}=169.34\end{array}$ & $\begin{array}{l}y=0.015 x+0.299 ; r^{2}=0.02 \\
p=0.228 ; F_{1,28}=1.52\end{array}$ & $\begin{array}{l}y=0.051 x+0.345 ; r^{2}=0.38 \\
p<0.001 ; F_{1,28}=18.96\end{array}$ \\
\hline 16. Pasma & $\begin{array}{l}y=0.058 x+0.077 ; r^{2}=0.77 \\
p<0.00 ; F_{1,28}=95.79\end{array}$ & $\begin{array}{l}y=0.020 x+0.280 ; r^{2}=0.06 \\
p=0.111 ; F_{1,28}=2.72\end{array}$ & $\begin{array}{l}y=0.108 x+0.099 ; r^{2}=0.74 \\
p<0.001 ; F_{1,27}=79.19\end{array}$ & $\begin{array}{l}y=0.315 x-0.527 ; r^{2}=0.63 \\
p<0.001 ; F_{1,22}=40.63\end{array}$ & $\begin{array}{l}y=0.036 x+0.214 ; r^{2}=0.66 \\
p=0.000 ; F_{1,28}=59.00\end{array}$ & $\begin{array}{l}y=0.069 x+0.032 ; r^{2}=0.68 \\
p<0.001 ; F_{1,28}=62.08\end{array}$ \\
\hline 17. Vaatto & $\begin{array}{l}y=0.048 x+0.257 ; r^{2}=0.42 \\
p<0.01 ; F_{1,12}=10.26\end{array}$ & $\begin{array}{l}y=0.169 x+0.095 ; r^{2}=0.62 \\
p=0.001 ; F_{1,11}=20.55\end{array}$ & $\begin{array}{l}y=0.201 x-0.018 ; r^{2}=0.69 \\
p<0.001 ; F_{1,28}=66.30\end{array}$ & $\begin{array}{l}y=0.444 x-0.963 ; r^{2}=0.73 \\
p<0.001 ; F_{1,26}=73.96\end{array}$ & $\begin{array}{l}y=0.020 x+0.413 ; r^{2}=0.18 \\
p=0.011 ; F_{1,28}=7.52\end{array}$ & $\begin{array}{l}y=0.038 x+0.275 ; r^{2}=0.48 \\
p<0.001 ; F_{1,28}=27.75\end{array}$ \\
\hline 18. Rattos & & $\begin{array}{l}y=0.123 x+0.177 ; r^{2}=0.68 \\
p=0.000 ; F_{1,28}=62.94\end{array}$ & $\begin{array}{l}y=0.145 x+0.254 ; r^{2}=0.25 \\
p<0.01 ; F_{1,28}=10.76\end{array}$ & $\begin{array}{l}y=0.257 x-0.040 ; r^{2}=0.79 \\
p<0.001 ; F_{1,24}=92.09\end{array}$ & $\begin{array}{l}y=0.042 x+0.272 ; r^{2}=0.50 \\
p=0.000 ; F_{1,28}=29.73\end{array}$ & $\begin{array}{l}y=0.077 x+0.086 ; r^{2}=0.72 \\
p<0.001 ; F_{1,28}=75.07\end{array}$ \\
\hline
\end{tabular}




\section{FIGUGE CAPTIONS}

Fig. S1. Bioaccumulation of $\mathrm{THg}$ using linear regression (solid line) and $95 \%$ confidence intervals (hatched line) between total length $(\mathrm{cm})$ and THg concentration ( $\mu \mathrm{g} \mathrm{\textrm {g } ^ { - 1 }}$ dry weight) in whitefish. Numbers in each figure refer to the study-lake order based on PC1 axis scores (see the corresponding lake names in e.g. Table 1$)$. Only significant $(p<0.05)$ regression lines are presented.

Fig. S2. Bioaccumulation of $\mathrm{THg}$ using linear regression (solid line) and $95 \%$ confidence intervals (hatched line) between total length $(\mathrm{cm})$ and THg concentration ( $\mu \mathrm{g} \mathrm{g}^{-1}$ dry weight) in vendace. Numbers in each figure refer to study-lake order according to PC1 axis scores (see the corresponding lake names in e.g. Table 1$)$. Only significant $(p<0.05)$ regression lines are presented.

Fig. S3. Bioaccumulation of $\mathrm{THg}$ using linear regression (solid line) and $95 \%$ confidence intervals (hatched line) between total length $(\mathrm{cm})$ and $\mathrm{THg}$ concentration ( $\mu \mathrm{g} \mathrm{g}^{-1}$ dry weight) in perch. Numbers in each figure refer to study-lake order according to PC1 axis scores (see the corresponding lake names in e.g. Table 1$)$. Only significant $(p<0.05)$ regression lines are presented.

Fig. S4. Bioaccumulation of $\mathrm{THg}$ using linear regression (solid line) and $95 \%$ confidence intervals (hatched line) between total length $(\mathrm{cm})$ and THg concentration ( $\mu \mathrm{g} \mathrm{g}^{-1}$ dry weight) in pike. Numbers in each figure refer to study-lake order according to PC1 axis scores (see the corresponding lake names in e.g. Table 1$)$. Only significant $(p<0.05)$ regression lines are presented.

Fig. S5. Bioaccumulation of THg using linear regression (solid line) and 95\% confidence intervals (hatched line) between total length $(\mathrm{cm})$ and $\mathrm{THg}$ concentration ( $\mu \mathrm{g} \mathrm{g}^{-1}$ dry weight) in roach. 
Numbers in each figure refer to study-lake order according to PC1 axis scores (see the corresponding lake names in e.g. Table 1$)$. Only significant $(p<0.05)$ regression lines are presented.

Fig. S6. Bioaccumulation of $\mathrm{THg}$ using linear regression (solid line) and $95 \%$ confidence intervals (hatched line) between total length $(\mathrm{cm})$ and THg concentration ( $\mu \mathrm{g} \mathrm{g}^{-1} \mathrm{dry}$ weight) in ruffe. Numbers in each figure refer to study-lake order according to PC1 axis scores (see the corresponding lake names in e.g. Table 1). Only significant $(p<0.05)$ regression lines are presented.

Fig. S7. Bioaccumulation of $\mathrm{THg}$ using linear regression (solid line) and $95 \%$ confidence intervals (hatched line) between age (years) and THg concentration ( $\mu \mathrm{g} \mathrm{g}^{-1} \mathrm{dry}$ weight) in whitefish. Numbers in each figure refer to study-lake order according to PC1 axis scores (see the corresponding lake names in e.g. Table 1). Only significant $(p<0.05)$ regression lines are presented.

Fig. S8. Bioaccumulation of $\mathrm{THg}$ using linear regression (solid line) and $95 \%$ confidence intervals (hatched line) between age (years) and THg concentration ( $\mu \mathrm{g} \mathrm{g}^{-1} \mathrm{dry}$ weight) in vendace. Numbers in each figure refer to study-lake order according to PC1 axis scores (see the corresponding lake names in e.g. Table 1). Only significant $(p<0.05)$ regression lines are presented.

Fig. S9. Bioaccumulation of $\mathrm{THg}$ using linear regression (solid line) and 95\% confidence intervals (hatched line) between age (years) and THg concentration ( $\mu \mathrm{g} \mathrm{g}^{-1} \mathrm{dry}$ weight) in perch. Numbers in each figure refer to study-lake order according to PC1 axis scores (see the corresponding lake names in e.g. Table 1$)$. Only significant $(p<0.05)$ regression lines are presented. 
Fig. S10. Bioaccumulation of THg using linear regression (solid line) and $95 \%$ confidence intervals (hatched line) between age (years) and THg concentration ( $\mu \mathrm{g} \mathrm{g}^{-1} \mathrm{dry}$ weight) in pike. Numbers in each figure refer to study-lake order according to PC1 axis scores (see the corresponding lake names in e.g. Table 1$)$. Only significant $(p<0.05)$ regression lines are presented.

Fig. S11. Bioaccumulation of THg using linear regression (solid line) and $95 \%$ confidence intervals (hatched line) between age (years) and THg concentration ( $\mu \mathrm{g} \mathrm{g}^{-1}$ dry weight) in roach. Numbers in each figure refer to study-lake order according to PC1 axis scores (see the corresponding lake names in e.g. Table 1). Only significant $(p<0.05)$ regression lines are presented.

Fig. S12. Bioaccumulation of THg using linear regression (solid line) and $95 \%$ confidence intervals (hatched line) between age (years) and THg concentration ( $\mu \mathrm{g} \mathrm{g}^{-1} \mathrm{dry}$ weight) in ruffe. Numbers in each figure refer to study-lake order according to PC1 axis scores (see the corresponding lake names in e.g. Table 1$)$. Only significant $(p<0.05)$ regression lines are presented.

Fig. S13. Assessment of putative relationships between PC2 (indicating lake morphometry; please note that opposite lake score values are used for clarity) and total length- (cm, uppermost row) and age-adjusted (second row) THg concentrations ( $\mu \mathrm{g} \mathrm{g} \mathrm{g}^{-1} \mathrm{dry}$ weight), as well as THg bioaccumulation rate relative to total length (cm, third row) and age (lower row). Roach was excluded from the analyses of THg bioaccumulation rate (Slope) due to low sample size. For equations see Table 3. No significant regressions were detected for any of the six species.

Fig. S14. Linear relationships between PC3 scores (indicating catchment magnitude; please note that opposite lake score values are used for clarity) and length- (cm, upper row) and age-adjusted 
916 (second row) THg ( $\mu \mathrm{g} \mathrm{g}^{-1}$ dry weight), as well as THg bioaccumulation rate (slope of lake and species917 specific linear regression) relative to total length (third row) and age (lower row). Only significant 918 regression (solid line) and 95\% confidence limits (hatched line) are presented. Roach was excluded 919 from the analyses of THg accumulation rate (Slope) due to low sample size. For equations see Table 9203. 

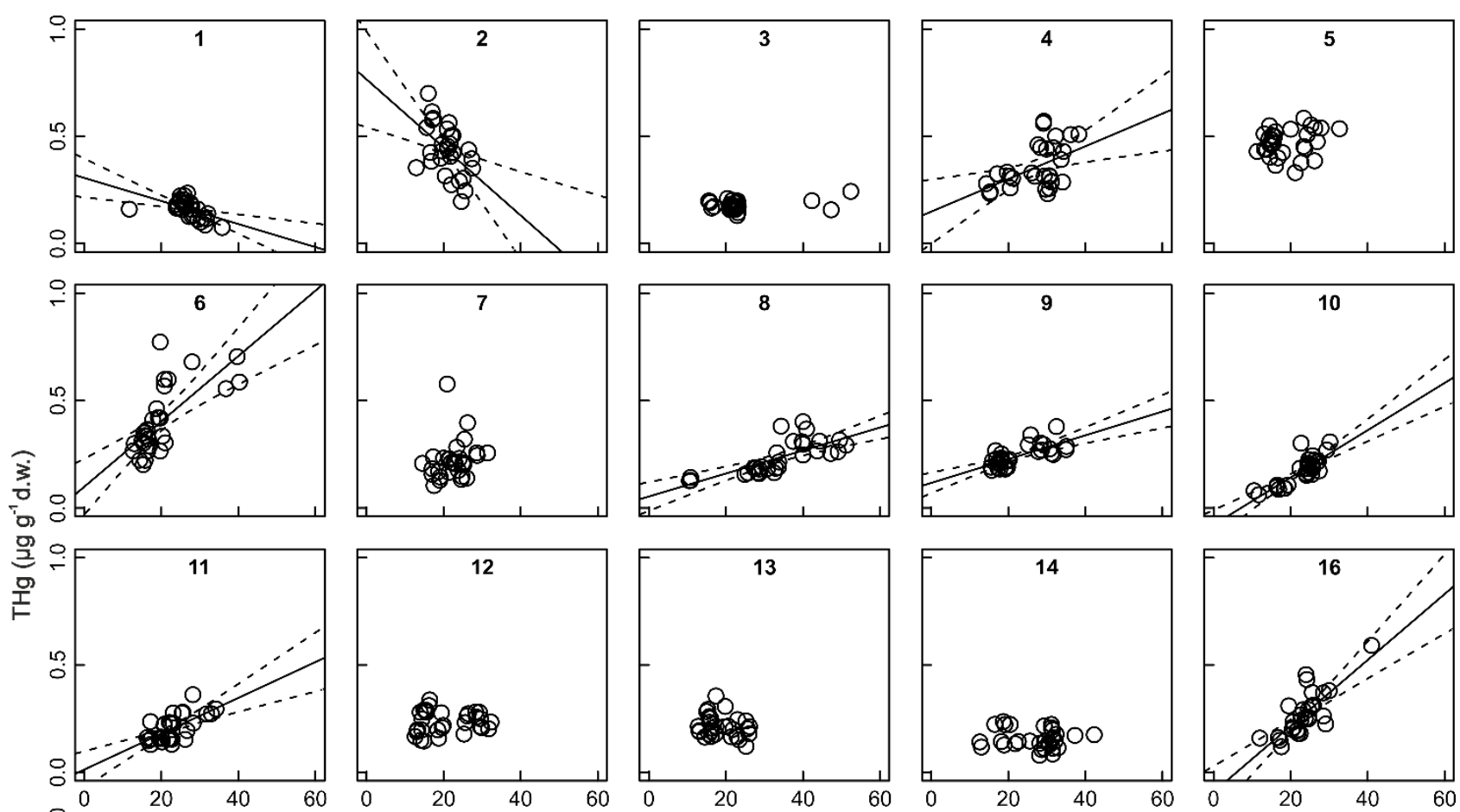

922

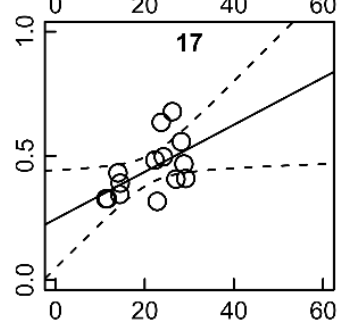

Total length $(\mathrm{cm})$

Fig. S1. Whitefish

924
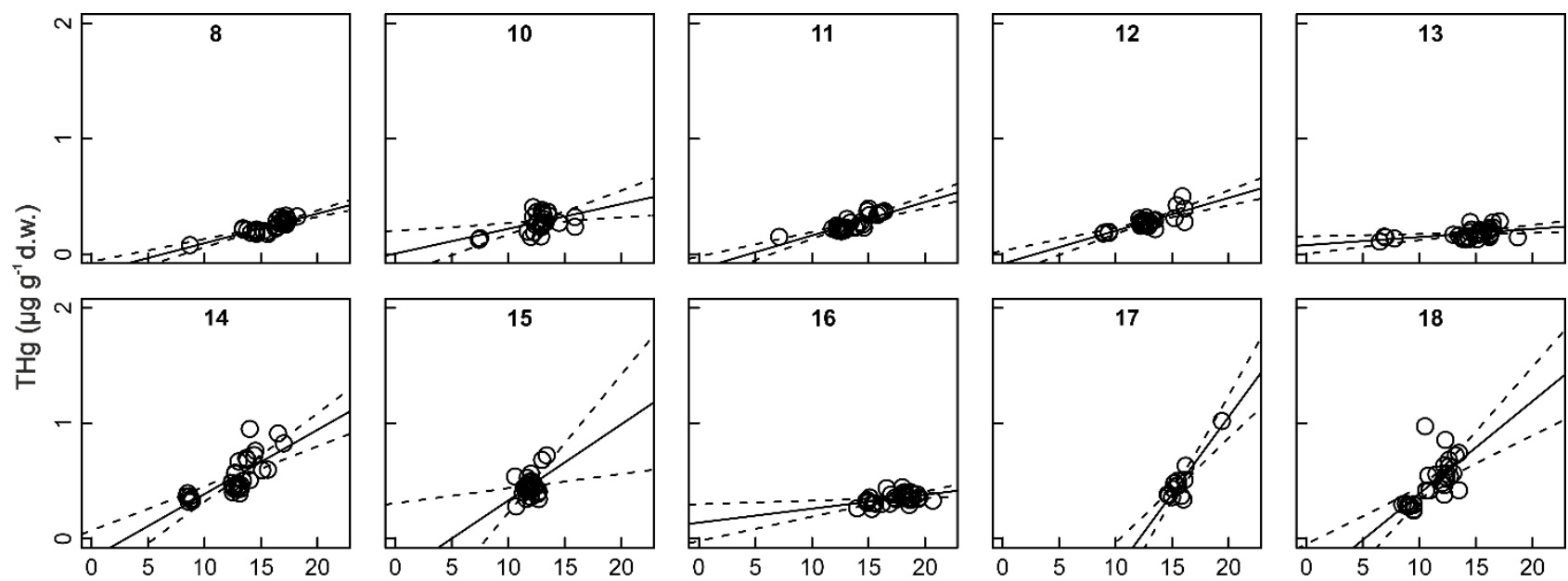

925
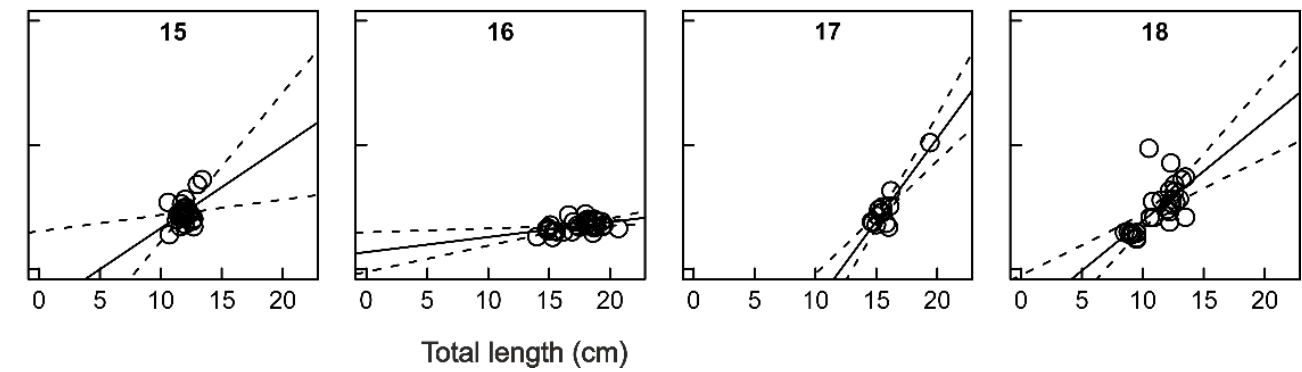

926

Fig. S2. Vendace

927 

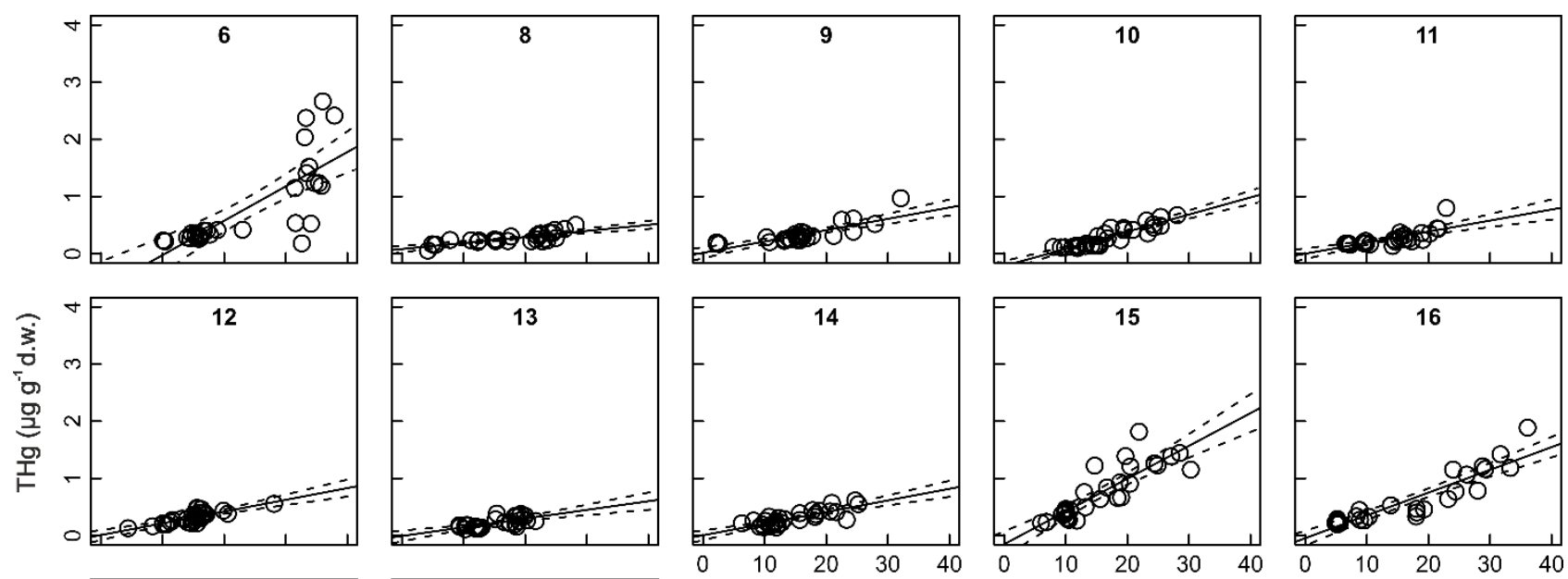

928
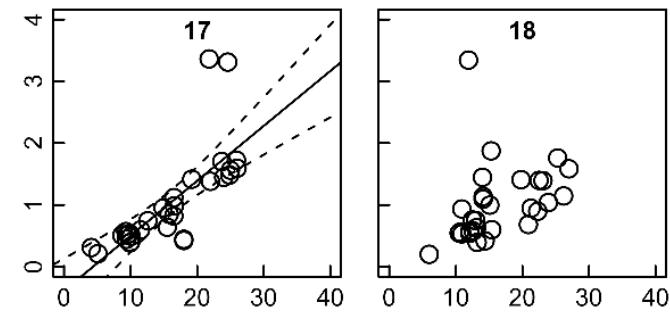

Total length $(\mathrm{cm})$

929

Fig. S3. Perch

930
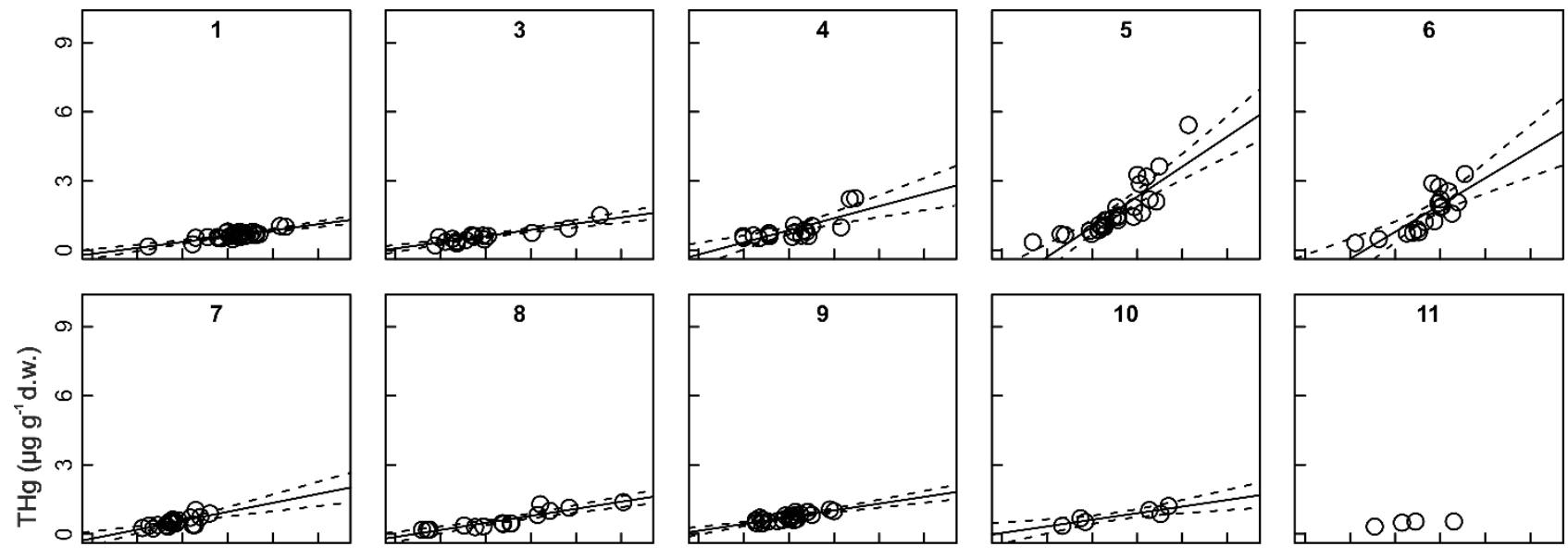

931
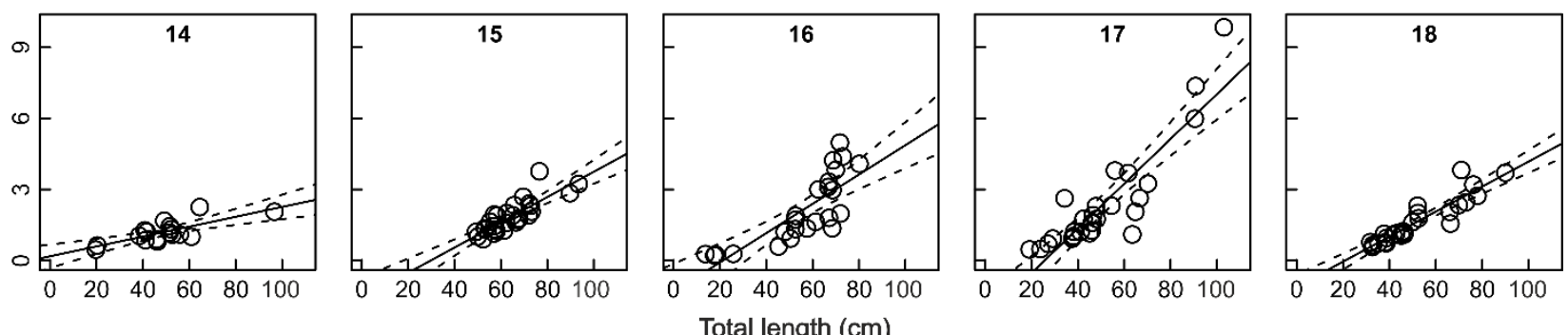

932

Fig. S4. Pike

933 

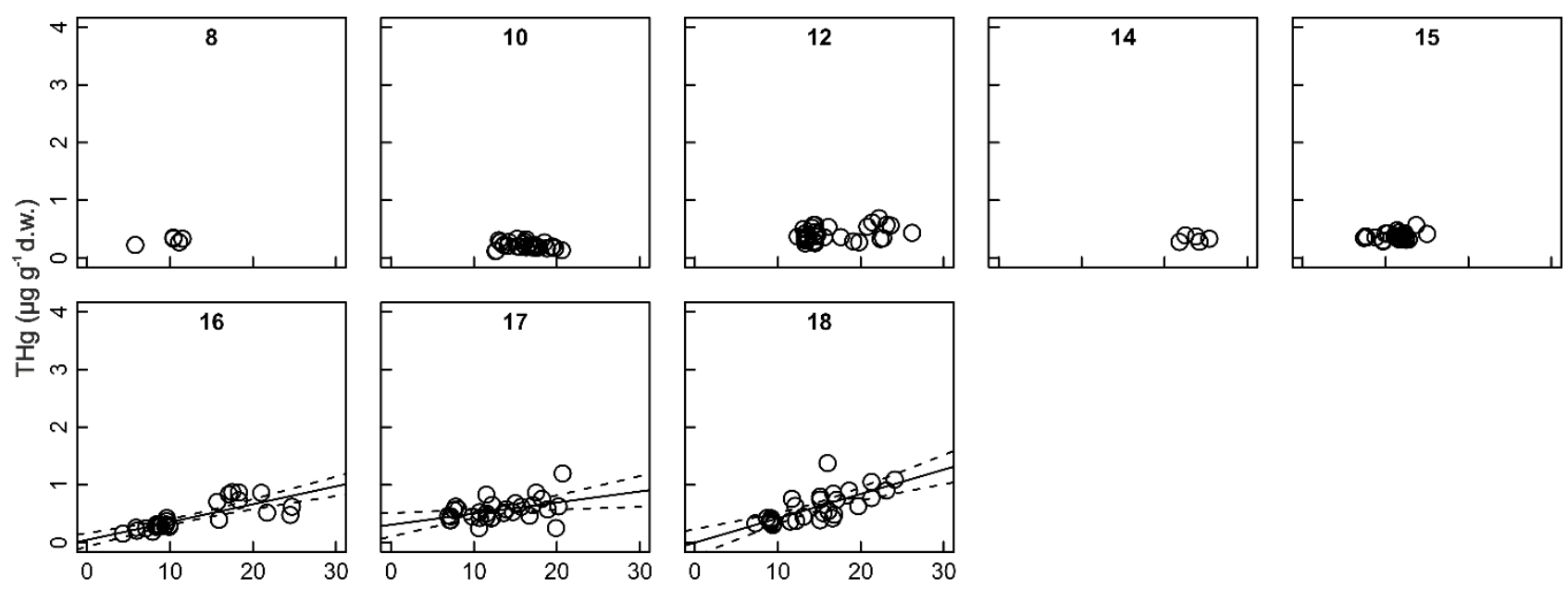

934
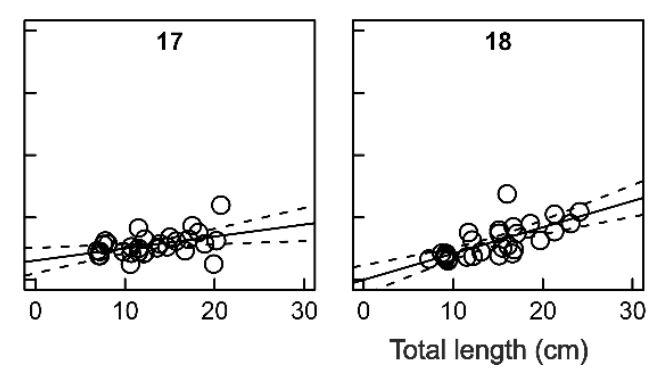

935

Fig. S5. Roach

936
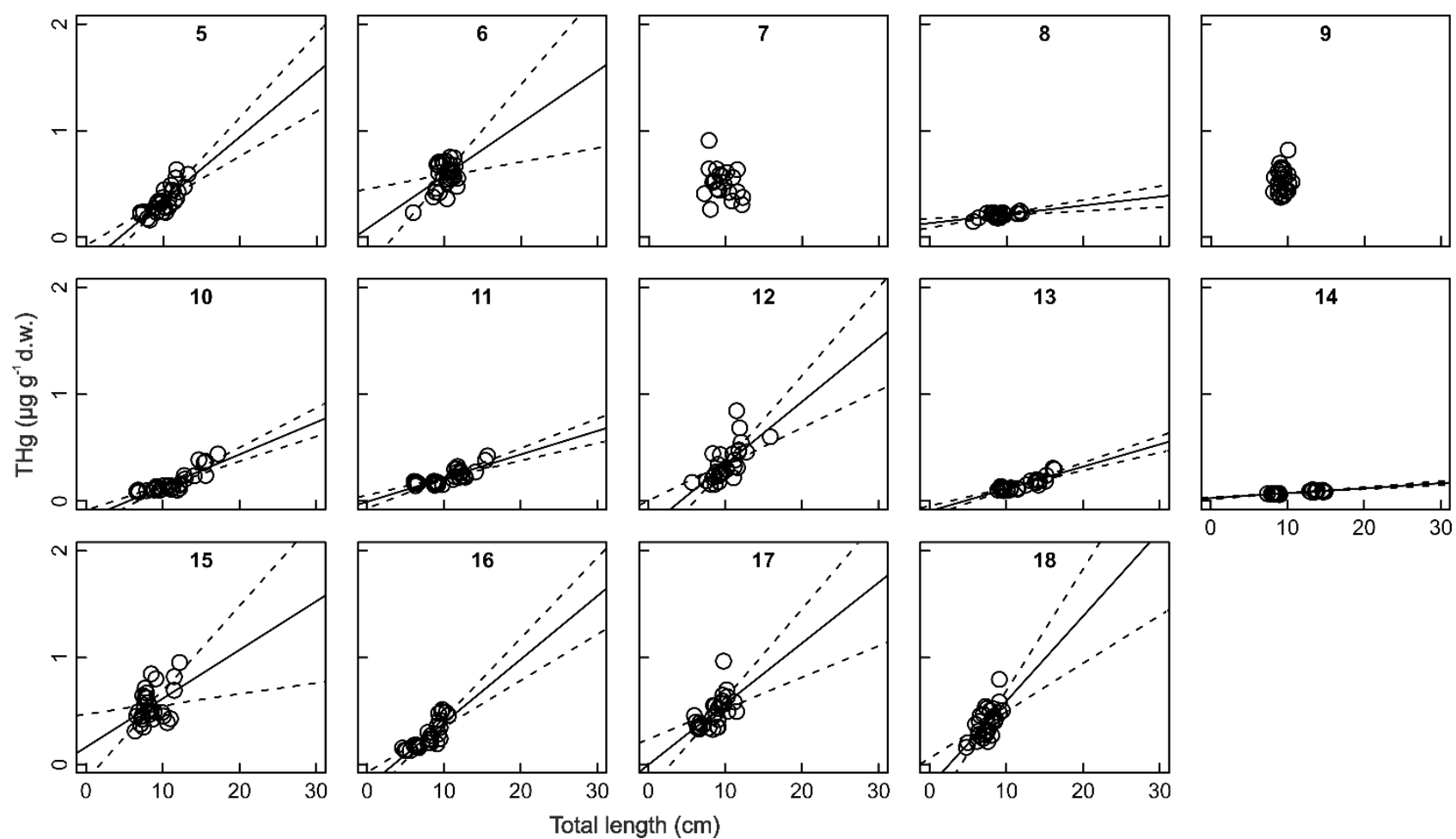

937

938

Fig. S6. Ruffe

939 

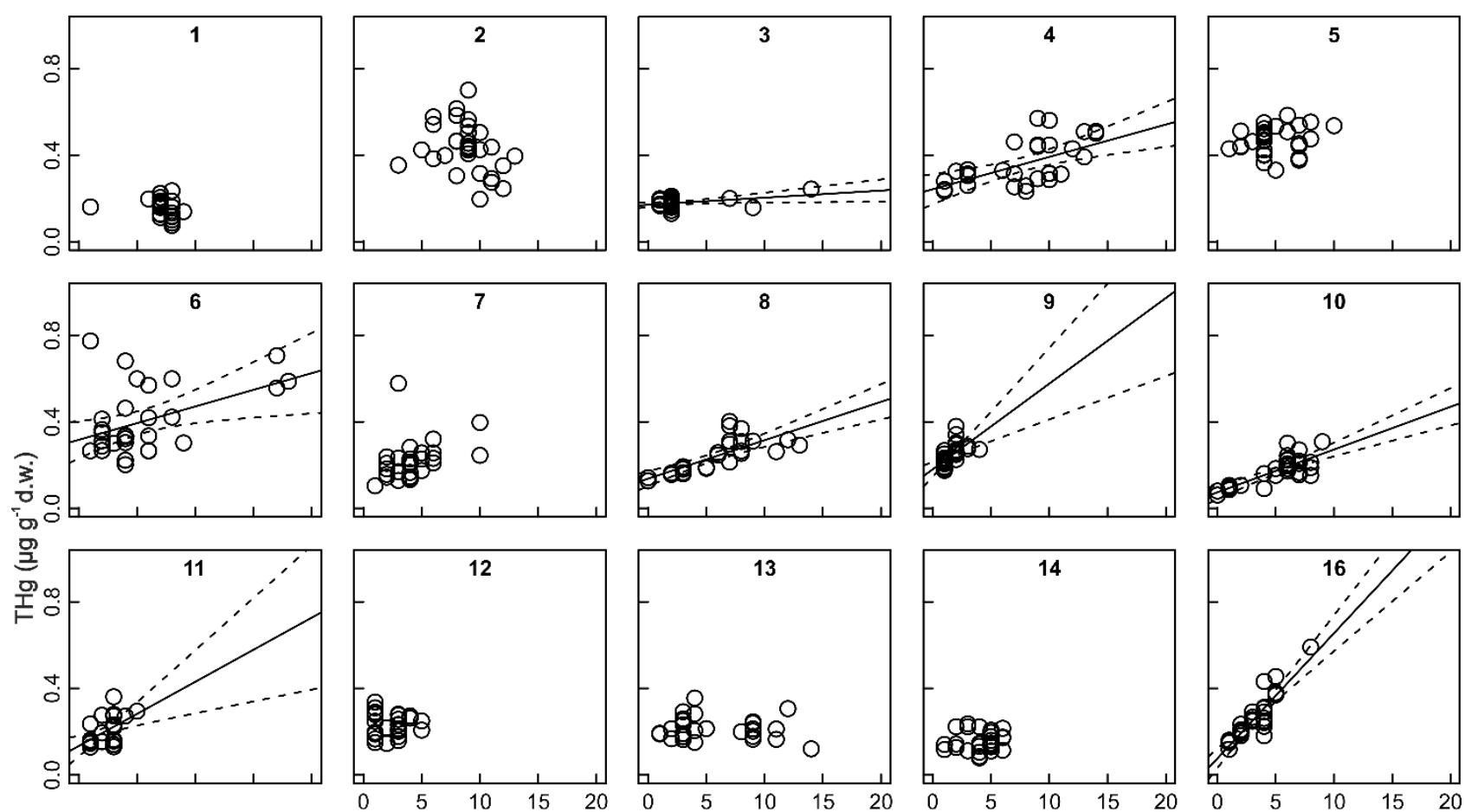

940

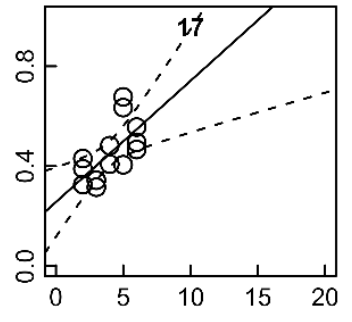

Age (years)

941 Fig. S7. Whitefish

942
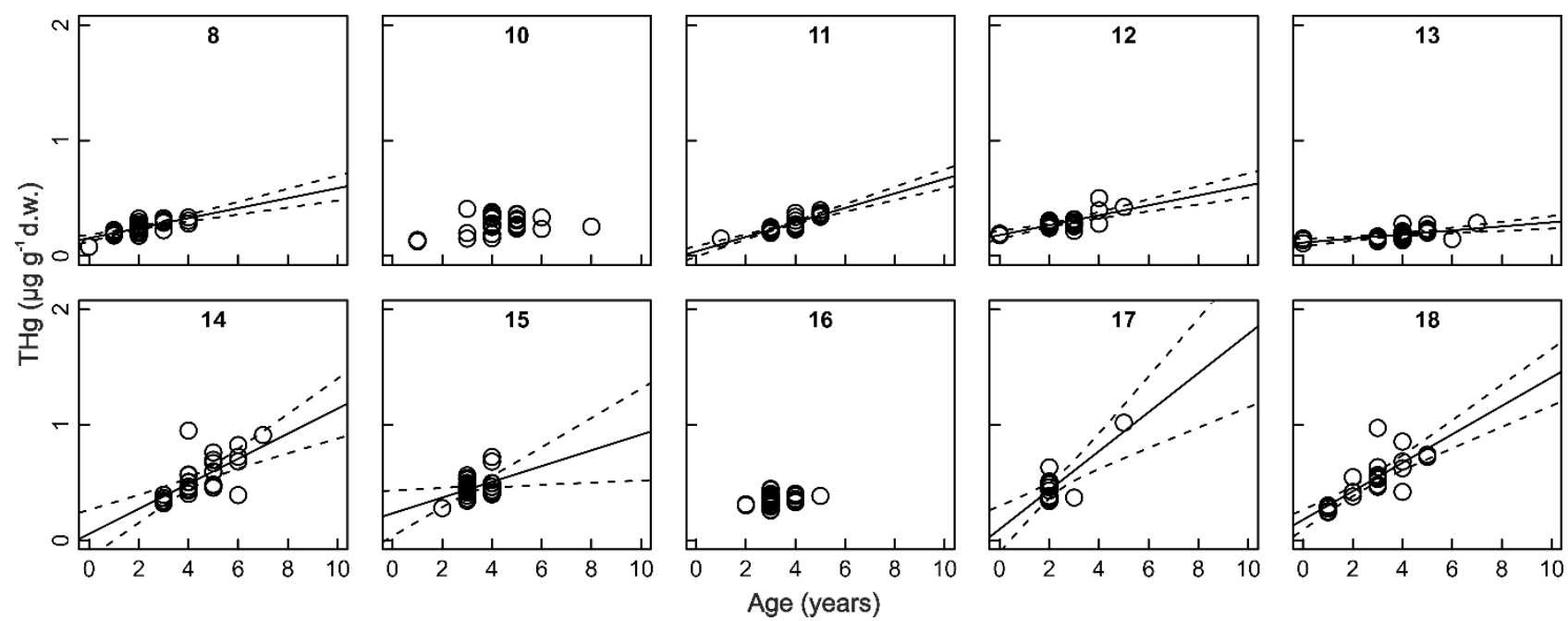

944 Fig. S8. Vendace 

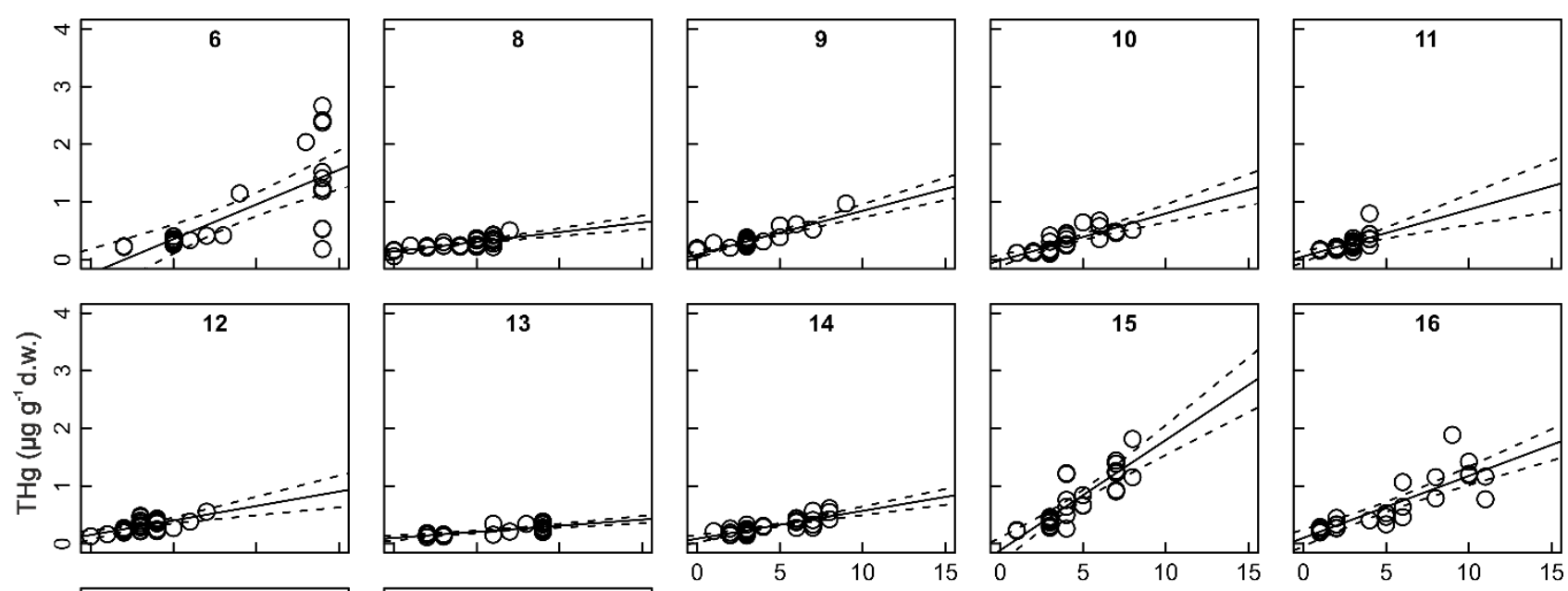

947
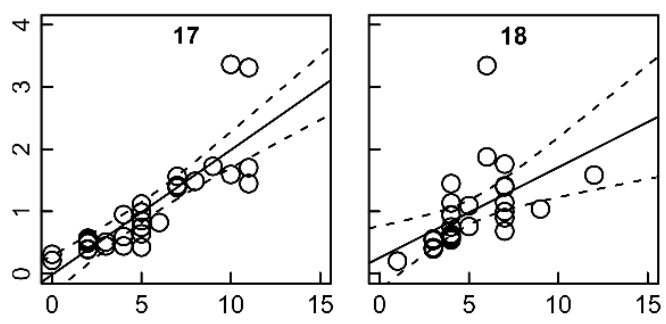

Age (years)

948 Fig. S9. Perch

949

950
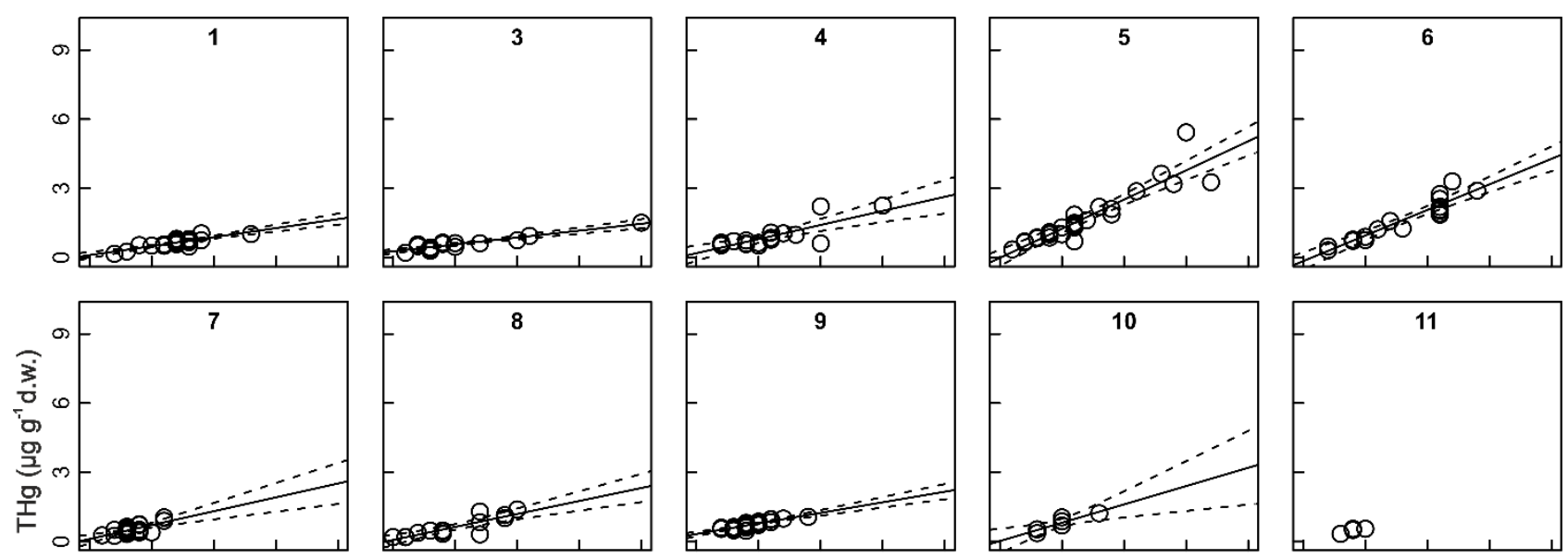

951
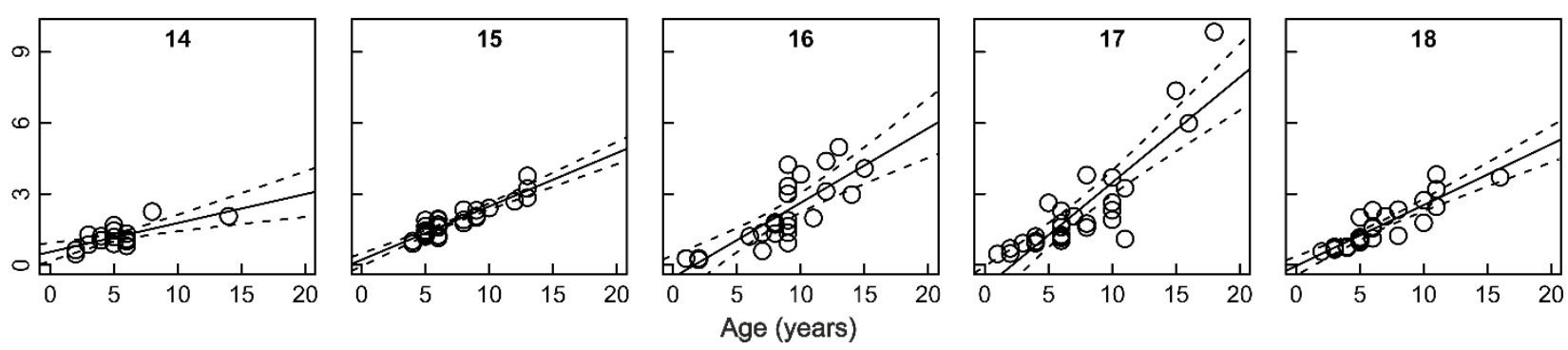

952 Fig. S10. Pike 

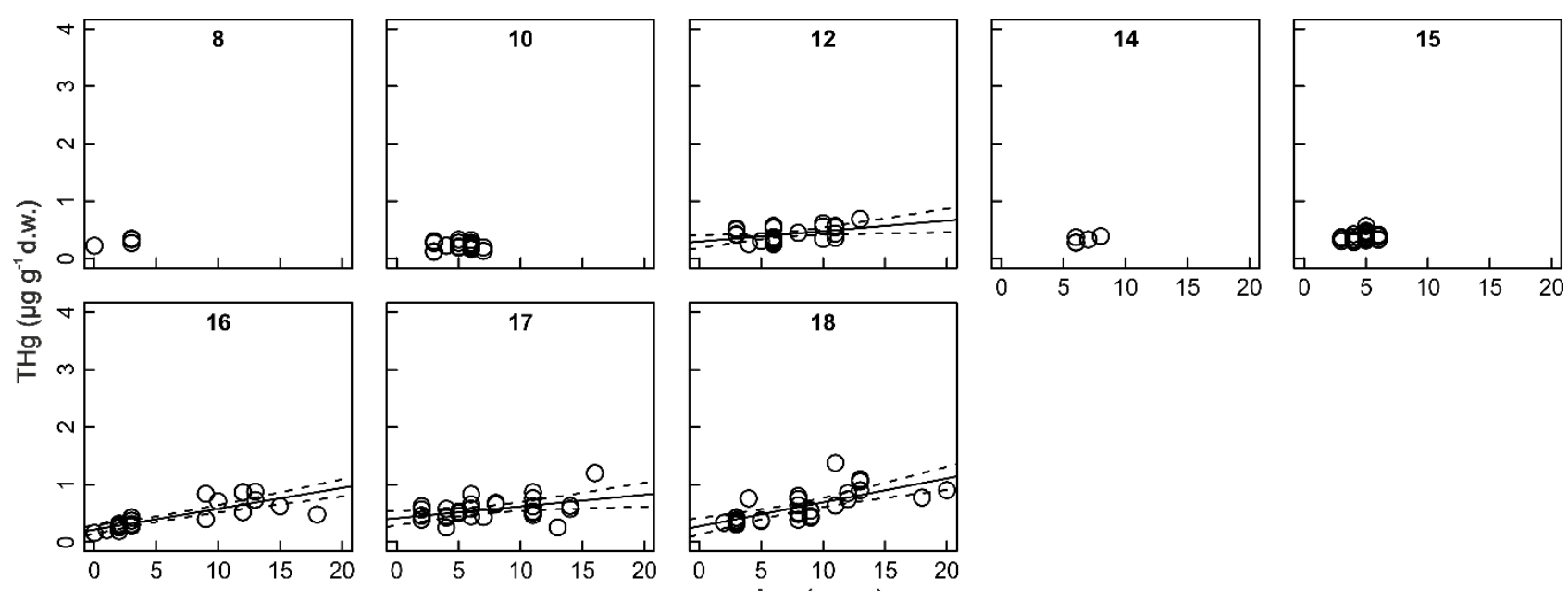

956
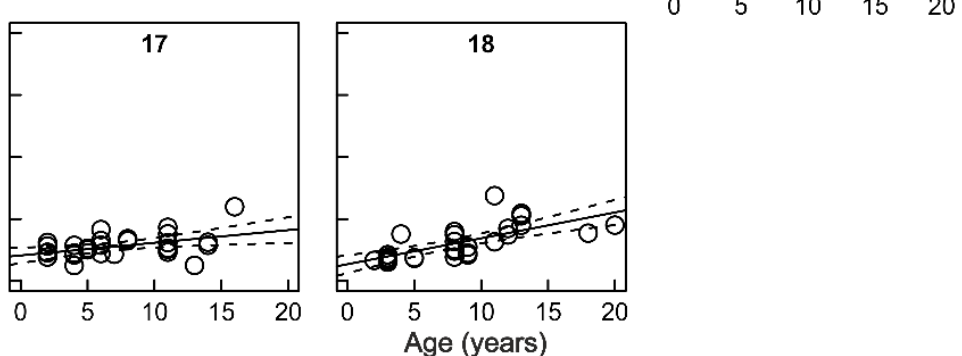

957
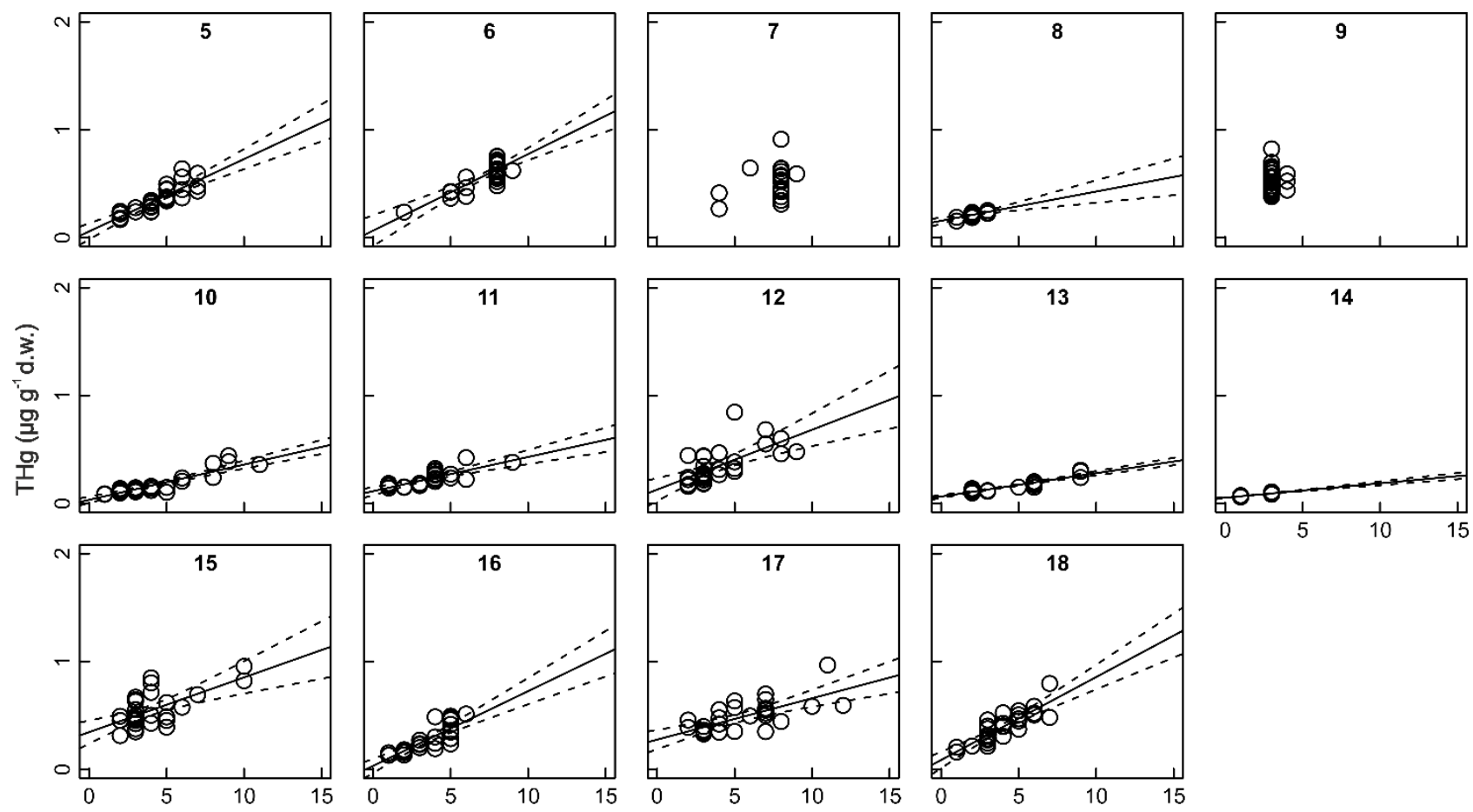

958
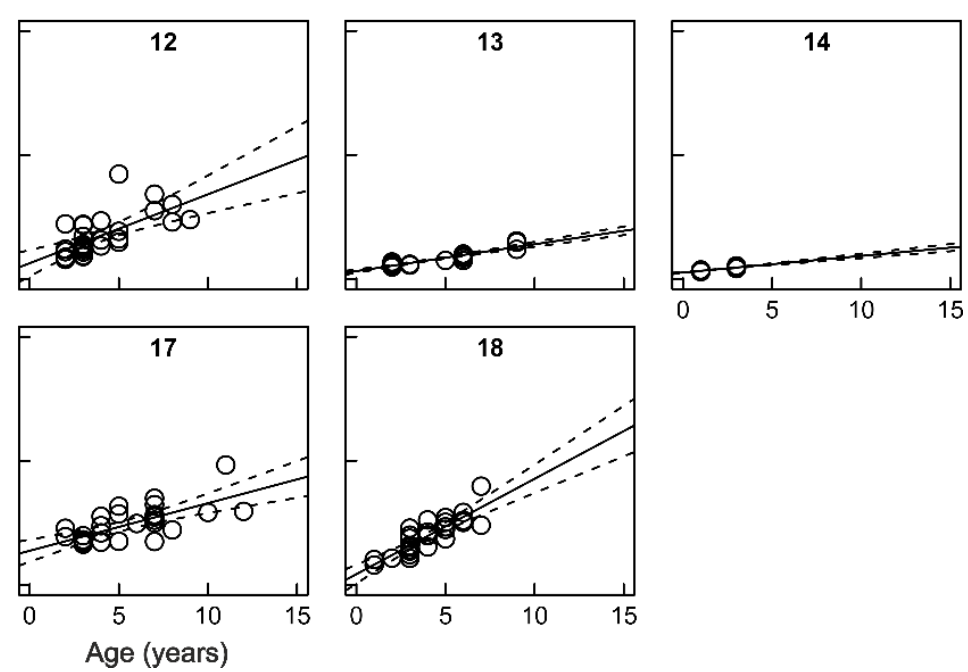

$959 \quad$ Fig. S12. Ruffe

960 

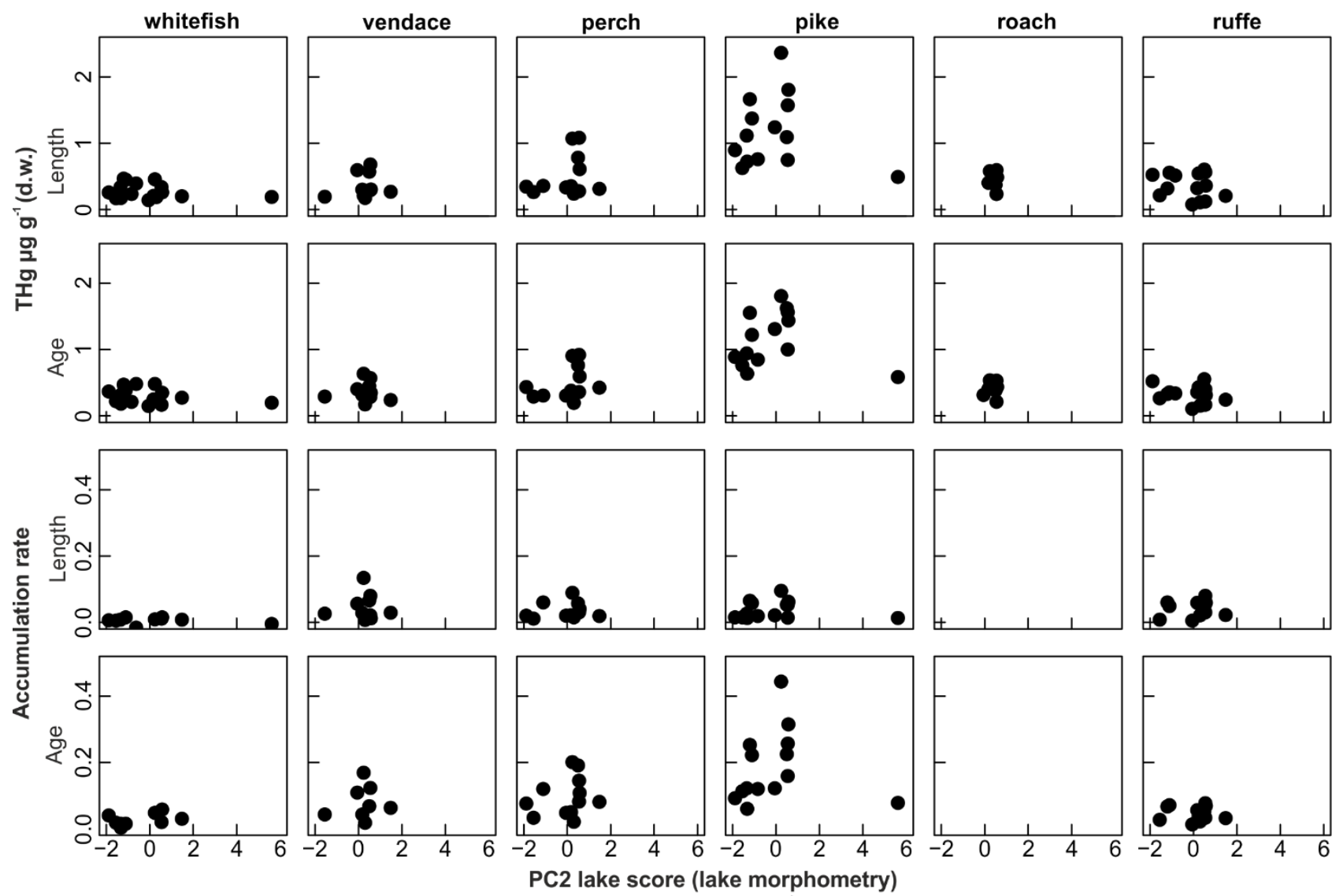

961

Lake size increases

962 Fig. S13. 

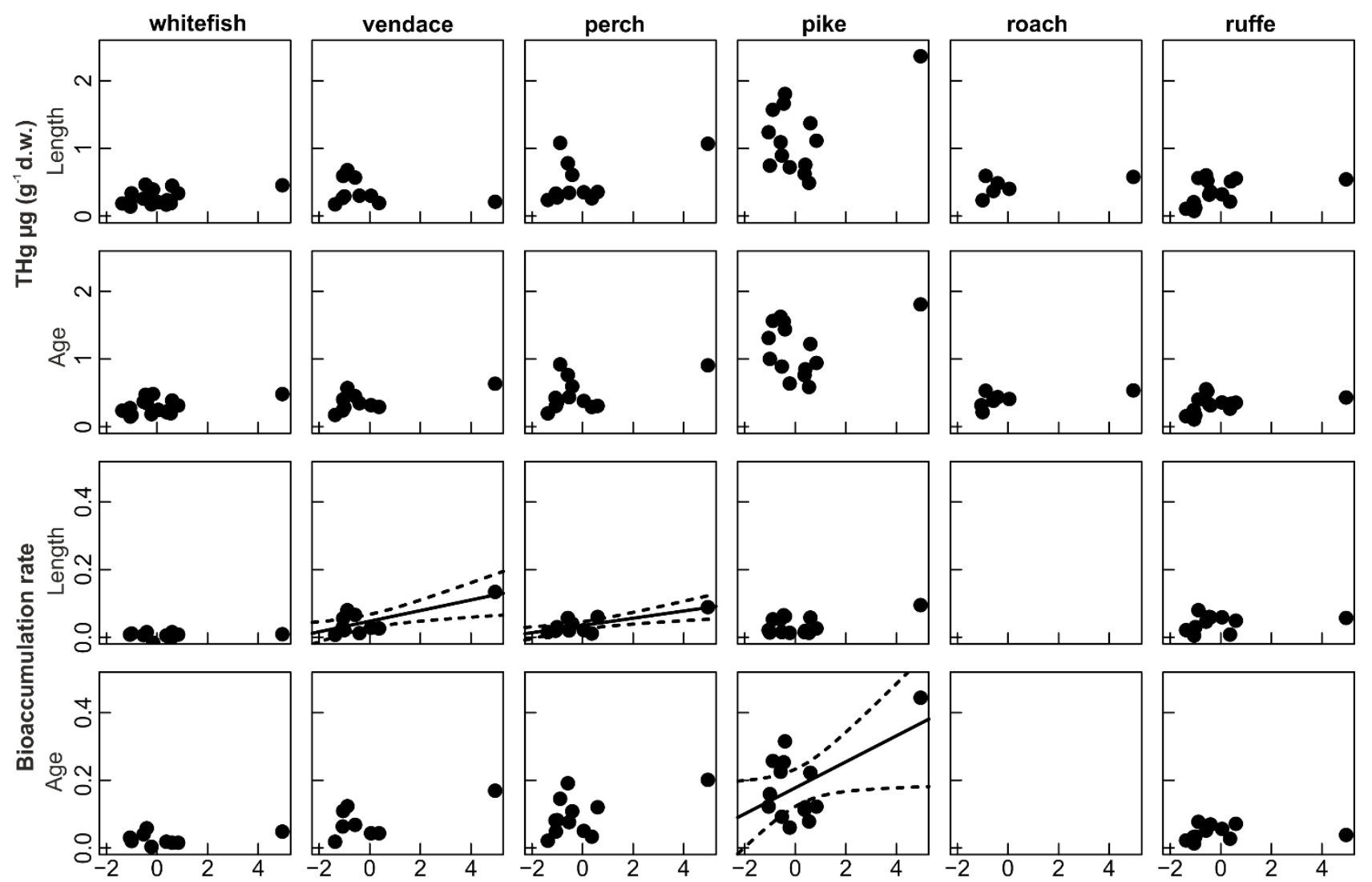

963
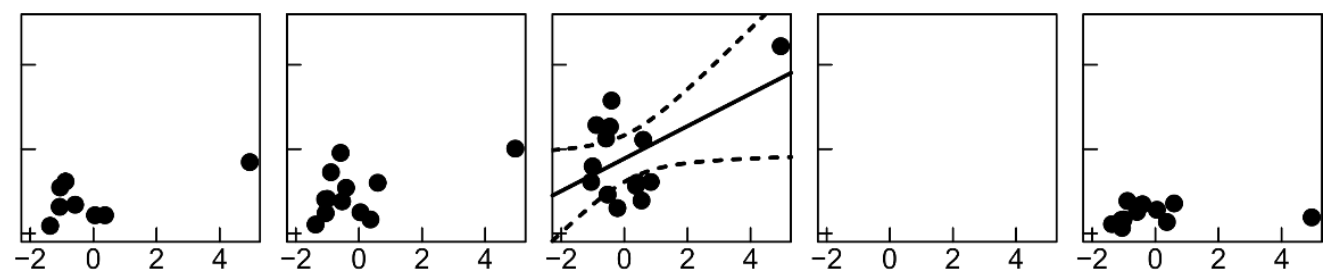

PC3 lake score (catchment magnitude increases)

964

Fig. S14 